\title{
PELAYANAN ADMINISTRASI UNTUK PROYEK BANGUNAN GEDUNG DALAM PERSPEKTIF PELAYANAN PUBLIK YANG BAIK
}

\author{
Edi As'adi
}

\section{BAB I \\ PENDAHULUAN}

\section{A. LATAR BELAKANG MASALAH}

Sejak diproklamirkannya kemerdekaan Indonesia tanggal 17 agustus $1945,{ }^{107}$ berdirilah Negara Indonesia. Selanjutnya, sebagai suatu negara, Indone sia memerlukan adanya aturan dasar yang memuat suatu Visi yang menjadi landasan arah tujuan dalam rangka mewujudkan cita-cita negara, menurut Barda Nawawi Arif menyatakan

bahwa setiap sistem mempunyai tujuan. Sistem ketatanegaraan, sistem pembangunan nasional, sistem pendidikan nasional, sistem pendidikan hukum dan sebagainya juga mempunyai tujuan (dikenal dengan istilah visi dan misi) ${ }^{108}$

Begitu juga dengan Visi Negara Kesatuan Republik Indonesia yang tertuang di dalam hukum dasar yang

\footnotetext{
107 Pramodiya, dkk, 1999, Kronik Revolusi Indoneia, Bagian 1 (1945), Cet.1, KPG, Jakarta dalam Arif Hidayat, 2006, Kebebasan Berserikat di Indonesia, Suatu Analisis Pengaruh Perubahan Sistem Politik Terhadap Penafsiran Hukum, hal. 64, Badan Penerbit Universitas Diponegoro, Semarang

108 Barda Nawawi Arif, 2009,Tujuan dan Pedoman Pemidanaan Perspektif Pembaharuan hukum Pidana Dan Perbandingan Beberapa Negara, hal.9, Percetakan Oetama, Semarang.
}

tertulis, ${ }^{109}$ yaitu pada UUD 1945 alenia keempat yang di antaranya berbunyi:

Kemudian daripada itu untuk membentuk suatu Pemeritahan Negara Indonesia yang melindungi segenap bangsa Indonesia dan seluruh tumpah darah Indonesia dan untuk memajukan kesejahteraan umum. Mencerdaskan kehidupan bangsa dan ikut melaksanakan ketertiban dunia yang berdasarkan kemerdekaan, perdamaian abadi dan keadilan sosial, maka disusunlah Kemerdekaan Kebangsaan Indonesia itu dalam suatu Undang-Undang Dasar Negara Republik Indonesia.

Dalam upaya mewujudkan kesejah teraan umum, telah dilakukan realisasi pembangunan nasional diseluruh sektor kehidupan masyarakat, khususnya sektor perumahan atau tempat tinggal dan infrastruktur lainnya sebagai penunjang tercapainya cita-cita mewujudkan kese jahteraan umum dan sekaligus sebagai penunjang terlaksananya kegiatan ke giatan masyarakat yaitu meliputi: ${ }^{110}$

\footnotetext{
109 Mahkamah Konstitusi Republik Indonesia, Oktober 2005, Undang-Undang Dasar Negara Republik Indonesia Tahun 1945 dan UndangUndang RI Nomor 24 Tahun 2003 Tentang Mahkamah Konstitusi, Cet.VIII, hal.12, Sekretariat Mahkamah Konstitusi RI, Jakarta

${ }^{110}$ Tim Redaksi Nuansa Aulia, 2008, Himpunan Peraturan Perundang-undangan Tentang Analisis Mengenai Dampak Lingkungan
} 
Jurnal Law reform April 2010. Vol. 5. No.1

(1) kegiatan kehidupan manusia dalam permukiman atau rumah atau tempat tinggal ; (2) Kegiatan sosial masyarakat dalam fasilitas-fasilitas sosial yang dibangun, taman-taman, tempat bermain, balai-balai pertemuan; (3) Kegiatan perekono mian dan perdagangan, misalnya pasar, pertokoan, pergudangan, pelabuhan dan hotel; (4) Kegiatan penunjang transpor tasi misalnya jalan tol, jalan kota, jem batan, terminal kota, terminal udara atau bandara dan pelabuhan laut; (5) Kegiatan olah raga dan rekreasi seperti lapangan golf, lapangan tenis, lapangan sepak bola dan sebagainya; (6) Kegiatan pariwisata, misalnya kebun binatang, atau wisata alam yang lain, daerah konservasi dan wisata buatan; (7) kegiatan pendidikan, yang memerlukan fasilitas gedung sekolah dan kampus; (8) kegiatan Indus tri kecil maupun besar dengan bangunanbanguan industri disertai fasilitas pe ngelolaan limbah: (9) kegiatan untuk me nunjang kesehatan masyarakat yang di lengkapi dengan fasilitas gedung rumah sakit, balai pengobatan, apotik, labora torium klinis, dan lain-lain: (10) kegiat an untuk pengamanan kota dan angkatan bersenjata misalnya fasilitas kantor polisi atau kemungkinan diperlukan ada nya fasilitas tempat latihan angkatan ber senjata tertentu.

Mengingat Indonesia sebagai negara yang berdasarkan hukum (rechs-staat)

(AMDAL), Cet. I, hal.236, CV. NUANSA AULIA, Bandung. yang bertujuan mewujudkan kesejah teraan umum, ${ }^{111}$ di bidang bangunan gedung, maka dalam menjalankan kegiatan-kegiatan pembangunan tersebut seyogyanya berdasarkan kepada kaidah hukum yang berisi kenyataan normatif atau apa yang semestinya dilakukan ${ }^{112}$ atau yang berlaku sebagai "aturan main"113 kegiatan kenegaraan, pemerin tahan dan kemasyarakatan yaitu UUD 1945 dan merujuk kepada undangundang organisnya yaitu UU Nomor 28 tahun 2002 tentang Bangunan Gedung.

Seiring meningkatnya jumlah pen duduk yang relatif banyak, maka dewasa ini pertumbuhan bangunan gedung pun juga relatif semakin banyak. Dalam penyelenggaraannya diperlukan adanya regulasi agar terwujud tertib bangunan gedung, dengan cara menentukan syaratsyarat teknis dan administratif yang harus dipenuhi oleh masyarakat yang hendak mendirikan bangunan gedung. Khususnya syarat administratif seperti ditentukan Pasal 7 ayat (2) dan Pasal 8 ayat (1) Undang-undang Nomor 28 tahun 2002 tentang Bangunan Gedung.

Meski demikian, untuk dapat me menuhi syarat administrasi untuk proyek bangunan gedung (baik berupa peru mahan dan atau pun menara pemancar telekomunikasi/BTS Pen.) sebagaimana ditentukan oleh perundang-undangan

\footnotetext{
111 Satjipto Rahardjo, 2006, Membedah Hukum Progresif, Cet.I, hal. XVIII,PT. Kompas Media Nusantara, Jakarta

Sudikno Mertokusumo, 2007, Mengenal ${ }_{13}$ Hukum, Cet. III, hal.16, Liberty, Yogyakarta

${ }^{113}$ Ibid., hal. 5
} 
tersebut di atas, masyarakat atau publik tidak mungkin mendapatkannya dengan cepat, mudah dan biaya yang terjangkau atau murah.

Namun sebaliknya untuk mendapatkan persyaratan administrasi yang di maksud semakin sulit dan mahal. Indikatornya adalah proses pelayanan administrasi untuk proyek bangunan gedung memerlukan waktunya relatif lama, berbelit dan terpisah, maka ber akibat biaya pelayanan administrasi un tuk proyek bangunan gedung menjadi mahal dan tidak menentu dan bahkan untuk memperoleh satu persyaratan ad ministrasi untuk proyek bangunan ge dung terkait kejelasan status hak atas tanah bisa menghabiskan waktu selama dua tahun. ${ }^{114}$

Seperti disinggung oleh Ketua Hari an YLKI, Sudaryatmo, dalam talk show yang digelar wartawan properti ibukota ,YLKI seperti dikutip harian Pelitaonline mengemukakan bahwa

Penegakan hukum di bidang hukum administrasi selama ini, termasuk di ibukota belum maksimal,". tidak maksimalnya penegakan hukum disebabkan masih minimnya regulasi di bidang perumahan dan secara kelembagaan instansi yang

\footnotetext{
${ }^{114}$ Wawasan, Minggu, 14 November 2010, Dua Tahun Sertifikat Tanah masih di Proses BPN, hal. 4, Wawasan Semarang."diterangkan bahwa proyek pelebaran jalan Kelurahan Pasar Batang, Dusun Sigempol, Desa Randusanga kulon Kecamatan Brebes kini menyisakan masalah, pasalnya, selama hampir dua tahun sertifikat warga yang terkena pembebasan tanah pada 2008 ternyata masih diproses Badan Pertanahan Nasional (BPN) atau Kantor Pertanahan Kabupaten Brebes.
}

berwenang mengeluarkan izin di bidang pembangunan perumahan masih menyebar yaitu pada Pe merintah Daerah dan BPN, ditam bah lemahnya koordinasi. Akibat nya, instrumen hukum administrasi belum efektif dalam rangka melin dungi kepentingan konsumen ${ }^{115}$ (garis bawah dari penulis)

Akibatnya, gejala yang timbul dalam penegakan hukum bangunan gedung di antaranya adalah relatif semakin banyak Penyelenggara proyek bangunan gedung beranggapan bahwa pemerintah dalam menyelenggarakan pelayanan administrasi untuk proyek bangunan gedung berorientasi profit making, tidak profesional dan dikelola layaknya lemba ga bisnis yang lengkap dengan ciri khas tawar menawar harga.

Sehingga berakibat di dalam penye lenggaraan proyek bangunan gedung muncul keengganan memenuhi persyara tan administrasi tersebut, dampaknya saat ini relatif semakin banyak bagunan gedung yang melanggar ketentuan ad ministrasi yang dipersyaratkan oleh Undang-Undang Nomor 28 tahun 2002 di atas.

Pada prinsipnya secara normatif Penyelenggaraan proyek konstruksi bangunan berlakunya dimulai sejak ditan datanganinya Surat Perjanjian Ker jasama (SPK) dan diterimanya Work Instruction dari Vendor kepada kon

\footnotetext{
115 Pelita, 2009, YLKI Menilai Penegakan Hukum Properti Lemah, www.pelitaonline.com
} 
Jurnal Law reform April 2010. Vol. 5. No.1

traktor atau sub-kontraktor, yang mana SPK tersebut berisi klausul-klausul dan kreteria spect bahan bangunan yang tertuang di dalam BOQ (Bill of Quantity) serta rencangan desain,

Selanjutnya SPK tersebut berlaku sebagai undang-undang bagi pihak-pihak yang membuatnya (baca Pasal 1338 KUHPerdata), namun kendalanya dalam pekerjaan persiapan (site aquisition atau Pekerjaan Pra-Implementasi antara lain IMB, sertifikasi Hak atas Tanah, Ijin Warga, goverment entity permit) Penyelenggara Proyek konstruksi bangunan dihadapkan pada substansi ketentuan normatif yang berlaku saat ini yaitu Undang-Undang Nomor 28 Tahun 2002 Tentang Bangunan Gedung.

Yaitu adanya gejala masalah yuridis normatif yang menjelma sebagai feno mena norma yang terdapat di dalam ke tentuan normatif yang berlaku sebagai undang-undang bagi pihak-pihak yang terkait di dalam SPK penyelenggaraan proyek konstruksi sebagai rujukan tindakan administrasi bertentangan dengan undang-undang atau aturan normatif yang berlaku sekarang ini atau dengan kata lain ditilik dari sisi herarki dan sinkronisasi hukum terdapat kesenjangan desparitas hukum positif (SPK) sebagai lex spesialist berhadapan (bukan ber tentangan) dengan normatif hukum sebagai lex generalist di atasnya, lain halnya dengan maksud 'hukum ber- tentangan dengan hukum' (hukum tidak sah). ${ }^{116}$

Selain itu juga kendala tersebut men jadi semakin kompleks ketuka diikuti penyimpangan (deviasi) penyelenggara pelayanan publik di bidang administrasi untuk proyek bangunan gedung. Hal ini pernah disinggung Presiden Susilo Bambang Yudoyono seperti dikutip Kompas Selasa 13 April 2010 lalu, Presiden mengatakan,

Bahwa demokrasi di suatu negara tumbuh dan berkembang dengan baik jika prosesnya dilakukan dengan menghindari politik uang, jika politik uang terjadi, hal itu bukan hanya mereduksi demokrasi atau kedaulatan rakyat. Melainkan akan menghasilkan pemimpin pemerintah yang melayani mereka yang membayar saja. ${ }^{117}$ (garis bawah dari penulis),

Atas dasar pemikiran tersebut penulis termotivasi untuk melakukan penelitian yang difokuskan kepada substansi ketentuan normatif yang terumus di dalam Undang-Undang Nomor 28 Tahun 2002 Tentang Bangunan Gedung yaitu meliputi persyaratan administrasi untuk proyek bangunan gedung meliputi; aspek status hak atas tanah, status kepemilikan bangunan gedung dan izin

\footnotetext{
${ }^{116}$ Hans Kelsen, 2009, Pengantar Teori Hukum (Introduction to the Problems of Legal Theory), Cet.II, hal115, Nusa Media, Bandung.

117 Kompas, 13 April 2010,Presiden: Politik Uang Bisa Hancurkan Demokrasi, Nomor 277 Tahun Ke-45, hal. 1, Kompas, Jakarta
} 
mendirikan bangunan dalam perspektif pelayanan publik yang baik atau ideal.

Berangkat dari pemikiran sebagaimana tersebut di atas maka agar dapat memperoleh kejelasan mengenai pelayanan administrasi untuk proyek bangunan gedung khususnya ditinjau dari ketentuan normatifnya yang ada saat ini, maka penulis memberikan judul kajian studi ini yaitu "Pelayanan Administrasi Untuk Proyek Bangunan Gedung Dalam Perspektif Pelayanan Publik Yang Baik".

\section{B. PERUMUSAN MASALAH}

Berdasarkan uraian di atas, maka parmasalahan sentral atau pokok yang menjadi obyek kajian studi ini yaitu:

1. Bagaimana Aspek Hukum Syarat Administrasi Untuk Proyek Bangunan Gedung Dalam Ketentuan Normatif Bangunan Gedung Yang Ada Sekarang?

2. Bagaimana Penegakan Hukum Bangunan Gedung Melalui Implementasi Undang-Undang Nomor 28 Tahun 2002 Tentang Bangunan Gedung dan kendala-kendalanya ?

3. Bagaimana Analisa Hukum Terhadap Substansi Implementasi Ketentuan Normatif Tentang Bangunan Gedung?

4. Bagaimana Aspek Hukum Syarat Administrasi Untuk Proyek Bangunan Gedung Dalam Perspektif Hukum Pelayanan Publik Yang Baik?
5. Bagaimana Politik Hukum Pelayanan Syarat Administrasi Untuk Proyek Bangunan Gedung Di Masa Akan Datang ?

\section{TUJUAN PENELITIAN}

Berangkat dari uraian permasalahan di depan, maka kajian studi ini bertujuan untuk:

1. Untuk menelaah dan mengkaji tentang Aspek Hukum Syarat Adminis trasi Untuk Proyek Bangunan Gedung Dalam Ketentuan Normatif Bangunan Gedung Yang Ada Sekarang

2. Agar dapat mengkaji lebih men dalam mengenai Penegakan Hukum Bangunan Gedung Melalui Imple mentasi Undang-Undang Nomor 28 Tahun 2002 Tentang Bangunan Gedung dan kendala-kendalanya

3. Untuk dapat lebih dalam menelaah dan mengetahui Analisa Hukum Terhadap Substansi Implementasi Ketentuan Normatif Tentang Bangunan Gedung

4. Untuk dapat mengkaji lebih dalam mengenai Aspek Hukum Syarat Administrasi Untuk Proyek Bangunan Gedung Dalam Perspektif Hukum Pelayanan Publik Yang Baik

5. Untuk mengetahui dan memahami Politik Hukum Pelayanan Syarat Administrasi Untuk Proyek Bangunan Gedung Di Masa Akan Datang 
Jurnal Law reform April 2010. Vol. 5. No.1

\section{MANFAAT PENELITIAN}

Selanjutnya dari hasil penelitian tersebut diharapkan diperoleh Manfaat atau kegunaan penelitian sebagai berikut:

1. Secara teoritis penelitian ini diharapkan dapat berguna untuk:

a. Memperoleh pemikiran dan wacana baru serta memberikan sumbangsih pada perkembangan keilmuan yang berkaitan dengan pelayanan administrasi untuk proyek bangunan gedung dalam perspektif pelayanan publik yang baik.

b. Memperdalam pengetahuan di bidang Hukum yang dapat memberikan kontribusi bagi pengembangan ilmu hukum yang ber kaitan dengan tugas pelayanan aparatur negara, khususnya dalam bidang Administrasi Bangunan Gedung.

2. Secara praktis Penelitian ini diharapkan dapat:

a. Memberikan sumbangan pemikiran konstruktif dan sistematis bagi pemerintah pusat dan daerah dalam hal pelayanan adminis trasi untuk proyek bangunan gedung

b. Memberikan wacana kepada pihak penyelenggara pelayanan publik dan bagi masyarakat da lam upaya mewujudkan harmo nisasi hak dan kewajiban antara yang memberikan pelayanan dan yang menerima pelayanan seba gai bukti wujud pemerintahan yang baik dan bersih.

\section{E. KERANGKA PEMIKIRAN}

\section{a. Kerangka Konseptual}

Kerangka Konseptual merupakan konsep-konsep dasar yang berkaitan dengan konsep-konsep yang terkandung dalam judul penelitian yang dijabarkan ke dalam permasalahan dan tujuan pe nelitian yang akan disajikan mengenai difinisi variable-variabel terkait berikut :

\section{(1) Pengertian Administrasi Ba- ngunan Gedung}

Administrasi berasal Bahasa

Belanda terdiri dari dua kata yaitu 'Ad 'berarti intensif dan kata 'ministratie' berarti melayani, membantu, memenuhi, merujuk pada kegiatan atau usaha untuk membantu, melayani, mengarahkan atau mengatur semua kegiatan dalam men capai suatu tujuan. ${ }^{118}$

Selanjutnya pengertian bangunan gedung seperti dijelaskan dalam Pasal 1 angka 1 Undang-Undang Nomor 28 Tahun 2002 adalah

wujud fisik hasil pekerjaan konstruksi yang menyatu dengan tempat kedudukannya (tanah dan air.Pen), sebagian atau seluruhnya berada di atas dan atau di dalam tanah dan atau air yang berfungsi sebagai tempat manusia melakukan kegiatannya, baik untuk hunian, atau tempat tinggal, kegiatan

\footnotetext{
118 Umpan Atom, 2009, Pengertian Pelayanan Umum, www.Wikipedia.com
} 
keagamaan, maupun kegiatan khusus.

Tujuan pemenuhan syarat administrasi di atas adalah agar dapat memberikan kepastian dan ketertiban hukum dalam rangka penyelenggaraan bangunan gedung yang sesuai aturan yang dipersyaratkan oleh pasal 7 ayat (2) dan pasal 8 ayat (1) UUBG 2002, yang keduanya diselenggarakan secara tertib yang dilandasi asas kemanfaatan, keselamatan, keseimbangan, dan keserasian bangunan gedung dengan lingkungannya, bagi kepentingan masyarakat yang berpri kemanusiaan dan berke adilan sosial.

Selanjutnya, secara normatif dapat ditarik satu konsep difinisi yang utuh tentang substansi administrasi bangunan gedung yaitu suatu rangkaian per syaratan dokumen-dokumen resmi yang diberikan oleh badan-badan administrasi negara kepada penyelenggara proyek bangunan gedung, adapun dokumen resmi tersebut meliputi surat atau Ser tifikat tanah sebagai bukti kejelasan hak atas tanah di mana hasil pekerjaan konstruksi tersebut akan berdiri, Surat ke pemilikan bangunan gedung yang di berikan oleh pemerintah daerah dan Izin Mendirikan Bangunan yang juga di berikan oleh pemerintah daerah sebagai wujud bahwa penyelenggaraan proyek bangunan gedung telah dijalankan sesuai ketentuan perundang-undangan yang ada.
(2) Pengertian Pelayanan Publik yang Baik

Pelayanan Publik, dalam kamus Bahasa Indonesia berasal dari kata Pelayan artinya orang yang melayani, dan publik berarti orang banyak atau umum. ${ }^{119}$ Dari dua arti kata tersebut, dapat dikatakan bahwa pada prinsipnya Pelayan Publik adalah orang atau organisasi secara sendiri-sendiri atau bersama-sama bekerja melayani kepentingan orang banyak atau masyarakat umum.

Sementara itu, menurut Ketetapan Menteri Pendayagunaan Aparatur Negara Nomor 63 / KEP/M.PAN/ 7/2003 seperti dikutip Juniarso Ridwan dan Achmad Sodik Sudrajad, menerangkan

Pelayanan Publik adalah segala kegiatan pelayanan yang dilaksanakan oleh penyelenggara pelayanan publik sebagai upaya pemenuhan ke butuhan penerima pelayanan mau pun pelaksanaan ketentuan pera turan perundang-undangan, yang dapat dikelompokkan menjadi tiga yaitu (1) Kelompok pelayanan ad ministrasi, (2) kelompok Pelayanan Barang, dan (3) kelompok pela yanan Jasa,. ${ }^{120}$

\footnotetext{
${ }^{119}$ S.Wojowasito, 1972, Kamus Bahas Indonesia Dengan Ejaan Yang Disempurnakan Menurut Pedoman Lembaga Bahasa Indonesia, Cet.V, hal 213 dan 227, Shinta Dharma, Bandung Baca juga di dalam J.S Badudu, Sutan Muhammad Zain, 2001, Kamus Umum Bahasa Indonesia, hal. 781-782, Pustaka Sinar Harapan, Jakarta.

${ }^{120}$ Juniarso Ridwan dan Achmad Sodik Sudrajad, 2009, Hukum Administrasi Negara Dan Kebijakan Pelayanan Publik, Cet. I, hal.19-20, Penerbit Nuansa, Bandung
} 
Jurnal Law reform April 2010. Vol. 5. No.1

Sedangkan, dalam Wikipedia ditemukan difinisi Pelayanan Publik., ada lah

segala bentuk jasa pelayanan baik dalam bentuk barang publik mau pun jasa publik yang pada prin sipnya menjadi tanggung jawab dan dilaksanakan oleh instansi pemerin tah di pusat, di daerah dan di lingkungan Badan Usaha Milik Negara atau Badan Usaha Milik Daerah dalam rangka upaya pemenuhan kebutuhan masyarakat maupun dalam rangka pelaksanaan ketentuan peraturan perundangundangan, ${ }^{121}$ yang pada setiap pro ses pelayanannya menyangkut sega la usaha yang dilakukan oleh sese orang atau sekelompok orang dalam rangka mencapai tujuan.

Senada pendapat di atas Moenir H.A.S menyatakan Pelayanan hakekat nya adalah

serangkaian kegiatan, karena itu merupakan suatu proses. Sebagai suatu proses, pelayanan berlang sung secara rutin dan berkesinam bungan, meliputi seluruh kehidupan orang dalam masyarakat. Pelaksa naan pelayanan dapat diukur, dan dapat ditetapkan standar baik dalam waktu yang diperlukan maupun hasilnya. Dengan adanya standar dalam pelayanan maka pada akhirnya dapat memberikan kepuas an pada pihak-pihak yang mendapat

\footnotetext{
121 Umpan Atom, 2009, Pengertian Pelayanan Umum, www.Wikipedia.com
}

layanan. ${ }^{122}$ (garis bawah dari Penulis).

Sesungguhnya pun manusia di ciptakan di dunia ini untuk saling tolong menolong dalam kebaikan sesama umat manusia, dan sesungguhnya pula Tuhan menghendaki kemudahan bagi setiap manusia dan tidak menghendaki kesukar an bagi setiap manusia. ${ }^{123}$.

Pemberian Pelayanan administrasi untuk proyek bangunan gedung sebagai salah satu bagian pelayanan publik oleh pejabat administrasi negara dalam arti sempit (bestuur) kepada masyarakat, me nunjukkan adanya indikasi hubungan timbal balik (konsensual. Pen) antara dua subjek hukum, artinya antara pelayan yaitu aparatur pemerintah dan yang dilayani yaitu masyarakat masingmasing memiliki Hak dan kewajiban yang harus saling sinergi. Yaitu adanya peran yang harus dilaksanakan disebut kewajiban dan peran yang tidak harus dilaksanakan yang disebut hak atau wewenang. ${ }^{124}$

Dalam kaitannya dengan pelayanan administrasi untuk proyek bangunan gedung, aparatur penyelenggara pelayanan sudah seyogyanya dapat me nempatkan masyarakat sebagai pelaku utama atau subyek hukum pembangunan di Indonesia, sedangkan pemerintah

\footnotetext{
${ }^{122}$ Moenir, H.A.S, 2001 dalam Leuwiliang-Bogor, 2009, Manajemen Pelayanan Umum di Indonesia, www.blogspot.com

${ }_{123}^{123}$ Al-Qur'an Surah; Al-Baqharah ayat 185

124 Soerjono Soekanto dan Sri Mamuji,1986, Penelitian Hukum Normatif Suatu Tinjauan Singkat, Cet II, hal. 12, Rajawali, Jakarta.
} 
berkewajiban untuk mengarahkan, membimbing, dan menciptakan suasana yang menunjang kegiatan masyarakat. ${ }^{125}$

Sedangkan dalam upaya pemerintah mengarahkan, membimbing dan menciptakan suasana yang menunjang kegiatan masyarakatnya sebagai penja baran Hukum Administrasi Negara me nurut Philipus M.Hadjon seperti dikutip Muin Fahmal mengatakan jangkauannya meliputi: ${ }^{126}$

1. mengatur sarana bagi penguasa untuk mengurus dan mengenda likan masyarakat

2. Mengatur cara partisipasi warga negara dalam proses pengaturan dan pengendalian

3. Mengatur tentang perlindungan hukum (rechtsbescherming)

Sementara itu, Menurut Prajudi Atmosudirdjo seperti dikutip Yos Johan Utama mengatakan

"hakekat dan cakupan Hukum Administrasi Negara adalah HAN mengatur wewenang, tugas, fungsi, dan tingkah laku para Pejabat Administrasi Negara". ${ }^{127}$

Senada dengan pendapat di atas, Van Wijk-Konjnenbeft dan P. de HaanCs

\footnotetext{
125 Departemen Dalam Negeri Dirjen Pemerintahan Umum, 2004, Modul Pelayanan Prima Lembaga Pelayanan Terpadu Satu Atap, Jakarta, Direktorat Jenderal Pemerintahan Umum, hal.5

${ }^{126}$ Muin Fahmal, 2006,Peran Asas-Asas Umum Pemerintahan yang Layak dalam Mewujudkan Pemerintahan yang Bersih, Cet. I, hal . 37, UII, Press, Yogyakarta.

127 Yos Johan Utama, tth, bahan Kuliah Power Point: "Menuju Hukum Administrasi Negara Yang Mensejahterakan dan Melindungi", hal. 28, Undip, Semarang lihat juga www.Scribe.com
}

seperti dikutip Yos Johan Utama me nyatakan bahwa hakekat dan cakupan Hukum Administrasi Negara adalah: ${ }^{128}$

a. Mengatur sarana bagi penguasa untuk mengatur dan mengenda likan masyarakat',

b. Mengatur cara-cara partisipasi warga negara dalam proses pe ngaturan dan pengendalian ter sebut;

c. Perlindungan hukum (rechtsbesherming);

d. Menetapkan norma-norma fundamental bagi penguasa untuk pemerintahan yang baik (algemene beginselen van behoorlijk bestuur)

Sementara itu, terkait penyeleng ga ra pelayanan publik, aparatur pemerintah dalam suatu organisasi merupakan profesional Administration (administrasi profesional) atau birokrasi, seperti di nyatakan oleh Randall B. Ripley dan Grace A Franklin dalam bukunya Policy Implementation and Bureaucracy (1982:32) seperti dikutip Kristian Widya Wicaksono menyatakan bahwa

Birokrasi pemerintahan berhubungan dengan urusan-urusan publik. Pada level yang umum, apabila birokrasi memberikan pelayanan publik dengan baik maka birokrasi tersebut mampu menunjukkan sejumlah indikasi prilaku berikut: (1) memproses pekerjaannya secara stabil dan giat; (2) memberlakukan individu yang berhubungan de-

${ }^{128}$ Ibid., hal. 28, Undip, Semarang 
Jurnal Law reform April 2010. Vol. 5. No.1

ngannya secara adil dan berimbang; (3) mempekerjakan dan memper tahankan pegawai berdasarkan kualifikasi profesional dan orientasi terhadap keberhasilan program. ${ }^{129}$

Yang tujuannya yaitu menyediakan sejumlah layanan sebagai hakikat dari tanggung jawab pemerintah.

Selanjutnya, dalam upaya mendorong percepatan transformasi penyelenggaraan pelayanan publik yang berkesinambungan, berkualitas, cepat, mudah, terjangkau dan terukur diperlukan adanya standar pelayanan yang dapat menjadi instrumen serta barometer bagi pemerintah atau penyelenggara pelayan an publik untuk melindungi warganya di mana pun mereka berada untuk mem peroleh akses yang sama terhadap kualitas dan kuantitas pelayanan ${ }^{130}$ publik, yang dimaksud adalah pelayanan administrasi untuk proyek banguan gedung.

\section{b. Kerangka Teoritik}

Pada hakekatnya pelayanan administrasi untuk proyek bangunan ge dung dari pejabat administrasi negara pada bidang administrasi bangunan ge dung terutama guna mewujudkan kesejah

\footnotetext{
${ }^{129}$ Kristian Widya Wicaksono, 2006, Administrasi dan Birokrasi Pemerintah, Cet.I Yogyakarta, Graha IImu, hal.9

Agus Dwiyanto, 2009, Revisi UU 32/2004:Latar Belakang dan Arah Perubahannya?, dalam Agus Pramusinto dan Erwan Agus Purwanto, Reformasi Birokrasi, Kepemimpinan dan Pelayanan Publik: Kajian tentang Pelaksanaan Otonomi Daerah di Indonesia, Cet.I, hal.77, Gava Media, Yogyakarta.
}

teraan merupakan sebuah hubungan hak dan kewajiban yang saling berhadapan dan tidak dapat dipisahkan.

Adanya hubungan timbal balik antara hak dan kewajiban di antara subyek hukum yang sama-sama memiliki kepentingan tersebut pada dasarnya harus seimbang dan selaras, atas dasar inilah diperlukan adanya hukum guna mengendalikan keadilan (law wants justice). Menurut Yahya Harahap me ngemukakan keadilan yang dikehendaki hukum harus mencapai nilai persamaan (equility), hak asasi individu (Individual Right), kebenaran (truth), kepatuhan (fairness), dan melindungi masyarakat (protection public Interest). ${ }^{131}$ Hukum dikatakan atau dianggap sanggup me negakkan nilai-nilai tersebut bilamana mampu bertahan dan mengantisipasi persoalan-persoalan kompleks yang di hadapi, dalam wujud hukum mampu meciptakan ketertiban-ketertiban pada se tiap sektor kehidupan (to achieve order), sehingga dari ketertiban yang tercipta dari hukum tersebut akan memberikan kepastian hukum dalam rangka pe negakan hukum (law enforcement) pada masa kini dan ataupun pada masa akan datang secara teringrasi dan berkesi nambungan.

Menyikapi hal ini, maka sudah sepatutnya pelayanan terhadap kepen-

\footnotetext{
${ }^{131}$ Yahya Harahap, 1997, Beberapa Tinjauan Tentang Permasalahan Hukum, Buku kedua, hal.54-55, Citra Aditya Bakti, Bandung dalam Alvi Syahrin, 2009, Beberapa masalah Hukum, cet.l, hal.4, Sofmedia, tanpa kota.
} 
tingan publik menjadi prioritas utama. Karena pada dasarnya Pelayanan administrasi untuk proyek bangunan gedung sebagai upaya awal untuk mempercepat program penciptaan tertib hukum atau penegakan hukum Bangunan Gedung (law inforcement) yang berorientasi pada pelayanan publik yang baik (law reform dan law development).

Menurut Nyoman Sarikat Putra Jaya mengatakan bahwa

penegakan hukum tidak hanya diartikan sebagai penerapan hukum positif (UU bangunan Gedung No.28 tahun 2002, PP No. 36 Tahun 2005, dan UU Pelayanan Publik dll, pen), tetapi juga penciptaan hukum positif $^{132}$ (Ius Constituendum.Pen).

Selanjutnya, hampir senada dengan pendapat tersebut Satjipto Rahardjo mengatakan

bahwa perspektif penegakan hukum apabila dilihat sebagai suatu proses, maka di dalamnya penegakan hukum tidak dilihat sebagai proses yang tertutup, melainkan melibatkan lingkungannya yang bertujuan mempertahankan hukum dan ketettiban. ${ }^{133}$

Terkait masalah pelayanan Administrasi Untuk Proyek Bangunan Gedung Nicolas Henry seperti dikutip oleh

\footnotetext{
132 Nyoman Sarikat Putra Jaya, 2008, Beberapa Pemikiran Ke Arah Pengembangan Hukum Pidana, Cet. I, hal. 52, PT.Citra Aditya Bakti, Bandung.

${ }^{133}$ Satjipto Rahardjo, 2009, Penegakan Hukum Suatu Tinjauan Sosiologis, Cet. I, hal. 11, Genta Publishing, Yokyakarta.
}

Wahyudi Kumorotomo, mengemukakan bahwa

Lokus administrasi negara adalah mengenai kepentingan publik ( $P u$ blic interest) dan urusan publik (public affairs), sedangkan fokusnya adalah teori organisasi dan ilmu manajemen. $^{134}$

Selanjutnya, pelayanan administrasi untuk proyek bangunan gedung sebagai urusan publik telah diatur dengan Pasal 7 ayat (2) dan pasal 8 Ayat (1) UUBG 2002 serta aturan Pelaksanaannya Peraturan Pemerintah Nomor 36 Tahun 2005 adalah merupakan bagian hukum administrasi khusus yaitu peraturan-peraturan hukum yang berhubungan dengan bidang tertentu dari kebijaksanaan penguasa seperti contoh hukum atas tata ruang dan hukum perizinan bangunan. ${ }^{135}$

Dengan demikian, regulasi tersebut sebagai wujud perintah dari penguasa atau pemerintah kepada Seluruh Warga Negaranya. Amos seperti dikutip Achmad Ali mengatakan hukum adalah

A command Proceeding from the supreme political authority of a state and addressad to the person

\footnotetext{
134 Nicholas Hanry, 1988, Administrasi Negara dan Masalah-masalah Kenegaraan, Rajawali, hal.33-65.Lihat juga John A Rihr, Ethics for Bureaucrats, op cit, hal.22-40. dalam Wahyudi Kumoroditomo. Ibid, hal. 121

${ }_{135}$ Philipus M.Hadjon, Sri Soemantri Marto Soewignjo, Syahran Basah, Bagir Manan, M.Laica Marzuki, J.B.J.M. ten Berge, P.J.J. van Buuren dan F.A.A. Stroink, 2008, Pengantar Hukum Administrasi Indonesia, Introduction to The Indonesian Administrative Law, Cet.X., hal.32, UGM Press, Yogyakarta.
} 
Jurnal Law reform April 2010. Vol.5. No.1

who are the subjects of that authority (yaitu suatu perintah yang dikeluarkan oleh penguasa politik tertinggi dari suatu negara, dan ditujukan terhadap person yang menjadi subyek kekuasaannya). ${ }^{136}$

Menurut Satjipto Rahardjo mengatakan, hukum adalah tatanan yang sengaja dibuat oleh manusia dan secara sengaja pula dibebankan kepadanya, ${ }^{137}$ hukum juga sebagai bagian dari usaha untuk menata ketertiban dalam masyarakat, ${ }^{138}$ khususnya ketertiban bangunan gedung.

Lebih lanjut Satjipto Rahardjo menambahkan bahwa hukum modern sarat dengan bentuk-bentuk formal, dengan prosedur-prosedur dan dengan birokrasi penyelenggaraan hukum, materi hukum dirumuskan secara terukur dan formal dan diciptakan pula konsep-konsep baru serta konstruksi khusus. ${ }^{139}$

Selanjutnya, Weber seperti dikutip Satjipto Rahardjo menyebutnya hukum sebagai legal rational, artinya menurut Satjipto Rahardjo hukum menjadi sarana yang makin diterima dan dipakai ${ }^{140}$ oleh setiap warga negara (perseorangan,

\footnotetext{
136 Achmad Ali, 2009, Menguak Teori Hukum (Legal Theory) dan Peradilan (Judicial Prudence) Termasuk InterPretasi UndangUndang (Legisprudence), Ed.I, Cet.I, hal. 421, Kencana Prenada Media Group, Jakarta Satjipto Rahardjo, 2007, Biarkan Hukum Mengalir, Catatan Kritis Tentang Pergulatan Manusia dan Hukum.Cet. I, hal. 7, PT. Kompas Media Nusantara, Jakarta

${ }^{138}$ Ibid., hal. 21

139 Ibid., hal. 7

140 Satjipto Rahardjo, 2009, Penegakan Hukum Suatu Tinjauan Sosiologis, Cet. I, hal. 137, Genta Publishing, Yokyakarta.
}

badan hukum, swasta ataupun pemerintah) di dalam menyelenggarakan proyek pembangunan di bidang bangunan gedung.

Mengingat betapa pentingnya penegakan hukum administrasi untuk proyek bangunan gedung Satjipto Raharjo berpendapat ada beberapa hal yang menarik dari ciri-ciri suatu administrasi pembangunan, yang layak juga dijadikan acuan (rujukan. Pen) pada saat memikirkan tentang ciri-ciri apa yang sebaiknya ada pada penegakan hukum untuk pembangunan, yaitu sebagai berikut: ${ }^{141}$

1. Mempunyai kesadaran lingkungan, artinya tindakan-tindakan dalam penegakan hukum hendaknya mengait kepada proses-proses yang berlangsung dalam masyarakat, seperti ekonomi, politik dan sebagainya.

2. Menyadari kedudukan dan kualifikasinya sebagai suatu badan yang harus ikut menggerakkan perubahanperubahan.

3. Penegakan hukum akan banyak terlibat kepada masalah pembuatanpembuatan keputusan dari pada sekedar menjadi badan yang melaksanakan saja.

Kemudian sehubungan Indonesia sebagai negara hukum memiliki sistem hukum yang meliputi tiga unsur, Unsur-

${ }^{141}$ Ibid., hal. 140-141 
unsur tersebut menurut L.M. Friedman yaitu: ${ }^{142}$

Struktur hukum terdiri atas keseluruhan institusi hukum beserta aparatnya, substansi hukum merupakan keseluruhan peraturan-peraturan, baik tertulis atau tidak tertulis dan kultur hukum adalah elemen sikap dan nilai sosial atau sebagai ide-ide, sikap-sikap, kepercayaan-kepercayaan, harapanharapan dan opini-opini tentang hukum.

Pendapat LM. Friedman di atas pernah disampaikan oleh mendiang Satjipto Rahardjo dalam artikelnya yang dicuplikkan dari dialog TVRI yang berbunyi

"Selama UUD kita dijalankan orang-orang berjiwa kerdil, maka

142 Lawrence M.Friedman diterjemahkan oleh M.Khozim, 2009, The Legal System A Social Science Perspective (New York:Russel Sage Foundation, 1975): Sistem Hukum Perspektif IImu Sosial,Cet.III, hal. 15-17, Nuansa Media, Bandung, Baca juga Achmad Ali, 2009, Menguak Teori Hukum (Legal Theory) dan Peradilan (Judicial Prudence) Termasuk InterPretasi Undang-Undang (Legisprudence), Ed.I, Cet.l, hal. 225-226, Kencana Prenada Media Group, Jakarta, baca juga Arif Hidayat, 2006, Kebebasan Berserikat di Indonesia, Suatu Analisis Pengaruh Perubahan Sistem Politik Terhadap Penafsiran Hukum, hal. 18, Badan Penerbit Universitas Diponegoro, Semarang, baca juga Esmi Warassih, 2005, Pranata hukum Sebagai Telaah Sosiologis, Cet.l, hal 81-82, PT.Suryandaru Utama, Semarang, baca juga dalam Nyoman Sarikat Putra Jaya, 2008, Beberapa Pemikiran Ke Arah Pengembangan Hukum Pidana, Cet. I, hal. 52, PT.Citra Aditya Bakti, Bandung baca juga dalam Muchtar Wahid, 2008, Memaknai Kepastian Hukum Hak Milik Atas Tanah, Cet.I, hal 80, Republika, Jakarta. impian dan cita-cita UUD tidak akan terwujud". ${ }^{143}$

\section{F. METODE PENELITIAN}

Metode penelitian dalam sebuah penelitian hukum adalah hal mutlak dilakukan agar hasil yang diperolehnya dapat objektif sesuai dengan kenyataan sebenarnya. menurut Soerjono Soekanto menjelaskan bahwa

penelitian hukum merupakan suatu kegiatan ilmiah, yang didasarkan pada metode, sistematika dan pemikiran tertentu, yang bertujuan untuk mempelajari satu atau beberapa gejala hukum tertentu, dengan jalan menganalisanya. Kecuali itu, maka juga diadakan pemeriksaan yang mendalam terhadap fakta hukum tersebut, untuk kemudian mengusahakan suatu pemecahan atas permasalahan-permasalahan yang timbul di dalam gejala yang bersangkutan. ${ }^{144}$

Dari difinisi yang dikemukakan Soerjono Soekanto di atas mengenai pengertian metode penelitian ${ }^{145}$, penulis

\footnotetext{
143 Kompas, Indonesia Jangan Menjadi Negara Hukum Kacangan, Kompas 19/8/2002 dalam Satjipto Rahardjo, 2006, Membedah Hukum ${ }_{144}$ Progresif; hal.5

Soerjono Soekanto, 1986, Pengantar Penelitian Hukum, Cet. III, hal.43, UI Press, Jakarta, baca juga dalam Mukti Fajar Nur Dewata \& Yulianto Achmad, Ibid., hal.27

${ }_{145}$ Sebagai wacana baca juga Piter Mahmud Marzuki, 2009, Penelitian Hukum, Ed. I, Cet V, hal.11, Prenada Media Group, Jakarta. Meskipun demikian H.J. van Eikema Hommes seperti dikutip Piter Mahmud Marzuki menyatakan bahwa setiap ilmu pengetahuan memiliki metodenya sendiri. Sedangkan penelitian hukum menurut Morris L. Cohen seperti dikutip Peter Maahmud Marzuki
} 
Jurnal Law reform April 2010. Vol.5. No.1

ingin menambahkah pendapat dari Robert R. Mayer dan Ernest Greenwood seperti dikutip Barda Nawawi Arif mengemukakan bahwa

Metode penelitian adalah suatu pendekatan umum ke arah fenomena yang telah dipilih (ditentukan) oleh peneliti untuk diselidiki. Selanjutnya dikemukakan, metode penelitian merupakan sejenis logika yang mengarahkan penelitian. ${ }^{146}$

Dalam hal ini Penulis melakukan Perumusan masalah secara deduktif seperti ini sesuai dengan hakekat penelitian sebagai suatu proses penemuan informasi yang benar melalui prosedur tertentu atau prosedur terstandar. Dengan prosedur tertentu ini diharapkan dapat memudahkan orang lain dapat mengikuti, mengulangi atau memeriksa kembali kesahihan (validitas) dan kemutakhiran

menyatakan bahwa "Legal Research is the process of finding the law that governs activities in human society........It involves locating both the rule which are enforced by the states and commentaries which explain or analyze these rules." (secara garis besar dapat diartikan secara sempit, bahwa penelitian hukum sebagai proses penemuan hukum dalam arti undang-undang yang diterapkan oleh Negara. Dan baca juga Soetandiyo Wignyosoebroto mengartikan Metode sebagai "cara", Selanjutnya, metode penelitian hukum adalah cara mencari (dan menemukan pengetahuan yang benar yang dapat dipakai untuk menjawab suatu masalah), cara pencarian ini sangat dikontrol ketat dan penuh disiplin. Semua itu diperolehnya hasil informasi serta simpulan yang dapat dipertanggungawabkan kebenarannya menurut tolok-tolok sains.

146 Robert R. Mayer dan Ernest Greenwood, op.cit., hal.80 dalam Barda Nawawi Arif, 2010, Kebijakan Legislatif Dalam Penanggulangan Kejahatan Dengan Pidana Penjara, Cet.IV, hal.61, Genta Publishing, Yogyakarta. atau keterandalan (reliabilitas) informasi yang diteliti. ${ }^{147}$.

Agar lebih intensif dalam mendiskripsikan atau menggambarkan metode penelitian yang digunakan dalam penelitian ini, penulis mensajikan metode penelitian ini dalam penjelasan pendekatan terhadap sentral permasalahan yang diteliti, ${ }^{148}$ spesifikasi penelitian, jenis data, metode pengumpulan data dan metode analisis data

\section{Pendekatan Masalah}

Dalam rangka memperoleh jawaban dan kejelasan atas pokok masalah mengenai pelayanan administrasi untuk proyek bangunan gedung dalam perspektif pelayanan publik yang baik, penulis menggunakan pendekatan yuridis-normatif, yaitu suatu proses untuk menemukan suatu aturan hukum, prinsipprinsip hukum, maupun doktrin-doktrin hukum untuk menjawab permasalahan hukum yang dihadapi ${ }^{149}$

Yang mana Penelitian hukum normatif ini ditunjang dengan pendekatan Perundang-undangan (Statute Approach), dilakukan dengan menelaah semua undang-undang dan regulasi yang bersangkut paut dengan isu hukum yang sedang ditangani ${ }^{150}$ atau diteliti dengan tetap

\footnotetext{
${ }^{147}$ Barda Nawawi Arif, 2010, Kebijakan Legislatif Dalam Penanggulangan Kejahatan Dengan Pidana Penjara, Cet.IV, hal.61, Genta Publishing, Yogyakarta.

${ }_{148}$ Ibid., hal.61

49 Piter Mahmud Marzuki, Ibid, hal. 35, baca juga dalam Mukti Fajar Nur Dewata \& Yulianto Achmad, Ibid, hal.34

${ }^{150}$ Piter Mahmud Marzuki, Ibid., hal.93
} 
berpedoman terhadap sistem kaidah hukum secara herarkis. ${ }^{151}$

Sebab, validitas kaidah hukum yang lebih rendah ditentukan oleh kaidah hukum yang lebih tinggi. Dan untuk menunjang Pendekatan perundang-undangan ini penulis melengkapinya dengan menggunakan pendekatan kasus (case Approach)

\section{Spesifikasi Penelitian}

Dalam penyusunan dan penulisan penelitian ilmiah ini, penulis akan mempergunakan salah satu spesifikasi penelitian yaitu diskriptif analitis, maksudnya adalah bahwa peneliti dalam menganalisis pokok permasalahan berkeinginan untuk memberikan gambaran atau pemaparan atas subjek dan objek penelitian sebagaimana penelitian yang dilakukan. Di sini peneliti tidak melakukan justifikasi terhadap hasil penelitiannya tersebut. ${ }^{152}$

\section{Jenis Data}

Lebih lanjut, dalam upaya menjawab dan menelaah permasalahan dan tujuan penelitian ini, diperlukan data primer dan data sekunder, akan tetapi penelitian ini menitikberatkan pada data skunder atau data kepustakaan atau juga

\footnotetext{
${ }^{151}$ Soerjono Soekanto, 1986, Faktor-Faktor Yang Mempengaruhi Penegakan Hukum, hal.45, Rajawali, Jakarta dalam Muchtar Wahid, 2008, Memaknai Kepastian Hukum Hak Milik Atas Tanah, Cet.l. hal. 83, Penerbit Republika, Jakarta.

152 Mukti Fajar Nur Dewata \& Yulianto
Achmad,lbid, hal.183
}

dikenal dengan bahan hukum, yaitu meliputi: ${ }^{153}$

a. Bahan hukum primer berupa perundang-undangan yang merupakan kesepakatan antara pemerintah dan rakyat sehingga mempunyai kekuatan mengikat untuk penyelenggaraan kehidupan bernegara. Dalam hal ini yaitu Undang-Undang Dasar 1945, Undang-Undang Nomor 28 tahun 2002 dan Peraturan Pemerintah Nomor 36 tahun 2005 tentang Bangunan Gedung, Undang-undang Pokok Agraria No.5 tahun 1960 dan Peraturan Pemerintah No.24 tahun 1997 tentang Pendaftaran Tanah,Undang-undang No. 28 tahun 1999 tentang Penyelenggara Negara yang Bersih dan Bebas Dari korupsi , Kolusi, dan Nepotisme, Undang-undang No. 14 tahun 2008 tentang Keterbukaan Informasi publik, UU No.25 Tahun 2009 tentang Pelayanan Publik, UU No. 4 Tahun 1992 Tentang Perumahan dan Permukiman, Undang-undang No.32 tahun 2009 tentang Lingkungan Hidup, Undang-Undang No. 26 Tahun 2007

\footnotetext{
153 Soerjono Soekanto dan Sri Mamudji, 1986, Penelitian Hukum Normatif, Cet.II, hal. 14-15, CV.Rajawali, Jakarta baca juga dalam Soerjono Soekanto, 1986, Pengantar Penelitian Hukum, Jakarta UI Press, hal.51-52 dan baca juga dalam Mukti Fajar dan Yulianto Achmad, Januari 2010, Dualisme Penelitian Hukum Normatif dan Empiris, Cet, I, hal.34-35, Pustaka Pelajar, Yogyakarta
} 
Jurnal Law reform April 2010. Vol. 5. No.1

tentang Tata Ruang Wilayah Peraturan Pemerintah No. 80 tahun 1999 tentang Kawasan Siap Bangun, PP No. 15 tahun 2010 sebagai perubahan PP No. 26 tahun 2007 tentang Tata Ruang Wilayah, PERMEN PU No. 24/PRT/M/2008 tentang Perawatan Bangunan Gedung, PERMEN PU No. 6/PRT/M/2007 tentang Tata Kelola Lingkungan, No. PERMEN PU No. 24/PRT/M/2007 Tentang Pedoman Teknis Izin Mendirikan Bangunan serta Putusan Mahkamah Agung RI No. 484 K/TUN/2007 tanggal 05 Maret 2008,mengenai sengketa Izin Mendirikan Bangunan di Jakarta Timur, Putusan Nomor : 144 K/TUN/1998 tanggal 29 September 1999 Sengketa Surat Perintah Pembongkaran Kios di Ujung Pandang dan Keputusan Mahkamah Agung Nomor 14 K/TUN/1992 Tanggal 10 Desember 1992 Perkara Pembatalan Hak Guna Bangun Yang Berdampak Pecabutan Izin Mendirikan Bangunan.di Jakarta Selatan.

b. Bahan hukum sekunder, yang memberikan penjelasan mengenai bahan hukum primer. meliputi bahan hukum yang diperoleh dari hasil penelitian, buku-buku teks, pamflet, lefleat, brosur, berita internet, surat kabar dan literaturliteratur hukum administrasi negara khususnya mengenai pelayanan administrasi pertanahan dan perizinan pembangunan gedung, dan seterusnya.

c. Bahan hukum tertier, memberikan petunjuk maupun penjelasan terhadap bahan hukum primer dan skunder yang berupa kamus, ensiklopedia, bebliografi, indeks komulatif dan leksikon dan seterusnya.

Selain bahan-bahan hukum di atas, dalam penelitian ini penulis melengkapi juga data-data dan dokumen-dokumen non- hukum yang memiliki relevansi dengan pokok permasalahan dalam penelitian ini, yang menjadi kompetensi instansi-instansi atau lembaga-lembaga terkait.

\section{Metode Pengumpulan data}

Metode pengumpulan data yang lazim digunakan dalam penelitian hukum normatif atau doktrinal adalah studi pustaka (literaturary studies) terhadap bahan-bahan hukum, baik bahan hukum primer berupa perundang-undangan, Peraturan Pemerintah, putusan pengadilan dll, bahan hukum skunder maupun bahan hukum tersier atau bahan nonhukum.

Bahan-bahan hukum tersebut da-pat dilakukan dengan membaca, melihat, mendengarkan, maupun sekarang banyak dilakukan penelusuran bahan hukum tersebut dengan melalui media 
internet. $^{154}$ Atau lebih konkritnya data skunder yang digunakan dalam penelitian ini di kumpulkan dari bahan hukum primer berupa perundangundangan dan yurisprudensi ${ }^{155}$

Dari sumber hukum skunder berupa dokumen atau risalah perundangundangan, sumber-sumber hukum dan perundang-undangan Negara lain, hasil kegiatan dan penelitian ilmiah lainnya baik nasional maupun Internasional, pendapat para ahli hukum dan ensiklopedia. ${ }^{156}$ Serta dikumpulkan pula bahan-bahan dari data skunder berupa publikasi ilmiah yang diperlukan sebagai referensi pada penelitian hukum normatif yang sepenuhnya mempergunakan data

154 Mukti Fajar dan Yulianto Achmad," Ibid, hal.160

${ }^{155}$ Oemar Seno adji, 1976, Hukum Acara Pidana dalam Propeksi, hal.74 dalam Barda Nawawi ${ }_{156}$ Arif, Ibid., hal.64

156 Yang termasuk sumber hukum skunder menurut Ervin H. Pollack, op.cit., hal.10 seperti dikutip Barda Nawawi Arif, ialah: (a) other-state of foreing sourses, (b) books of search (antara lain encyclopedias), (c) books of index dan (d) opinions of legal experts, sedangkan Morris L.Cohen, op.cit., hal.6-7 seperti dikutip Barda Nawawi Arif menyebutkan: histories and surveys of law, constitutional convention and documents, foreing and comparative report and studies, texts, commentaries, monograph, encyclopedias. Sedangkan J.M. Jacobstein and R.M. Mersky, op.cit., hal.5 yang dikutip Barda Nawawi Arif memasukkan: (a) writings of lawyers dan (b) the publication of law reform organization, Ronny Haninto Soemitro, op.cit., hal. 25 dan Soerjono, op.cit., hal.15 dikutip Barda Nawawi Arif, menyebut (a) Rancangan peraturan perundang-undangan, (b) hasil karya ilmiah para sarjana dan (c) hasil-hasil penelitian. Berbeda dengan Ervin H.Pollack di atas, Soerjono Soekanto, op.cit., hal.19 dan 41 yang dikutip Barda Nawawi Arif memasukkan ensiklopedia sebagai bahan hukum tertier yang oleh Piter Mahmud marzuki, Ibid., hal. 143 dan 163 diistilahkan bahan non hukum. skunder, maka penyusunan kerangka teoritis yang bersifat tentative (percobaan) dapat ditinggalkan.

\section{Metode Analisa Data}

Dari data-data sekunder yang telah terkumpul, selanjutnya dilakukan analisis secara kualitatif normatif yaitu dengan cara mendekati makna dan ketajaman analisis logis (normatif) dan juga dengan cara menjauhi statistik sejauh-jauhnya ${ }^{157}$ atau dengan cara melakukan penyorotan terhadap masalah dan pemecahannya, yang dilakukan dengan upaya-upaya yang banyak didasarkan pada pengukuran yang memecahkan obyek penelitian ke dalam unsur-unsur tertentu, untuk kemudian ditarik suatu generalisasi yang seluas mungkin ruang lingkupnya. ${ }^{158}$

Pada dasarnya, menurut Soerjono Soekanto mengatakan bahwa pendekatan kwalitatif normatif ini sebenarnya merupakan tata cara penelitian yang menghasilkan data diskriptif analitis yaitu apa yang dinyatakan oleh obyek penelitian (nara sumber) secara tertulis atau lisan dan prilakunya yang diteliti dan dipelajari sebagai sesuatu yang utuh. ${ }^{159}$

\footnotetext{
${ }^{157}$ Burhan Bungin, 2001, Metodologi Penelitian Kualitatif, Ed.I, Cet.V hal.27, Rajagrafindo

Persada, Jakarta.

${ }^{158}$ Soerjono Soekanto, 1986, Pengantar

Penelitian Hukum, Cet III, hal 32 dan 250-251

UI-Press, Jakarta

${ }^{159}$ Soerjono Soekanto, 1986, Ibid......, Cet III, hal

32, UI-Press, Jakarta
} 
Jurnal Law reform April 2010. Vol.5. No.1

\section{G. SISTEMATIKA PENULISAN}

Agar memudahkan dalam menelaah dan mengkaji permasalahan yang menjadi fokus penelitian ini, penulis mensistematisasikannya ke dalam empat bab, diawali dengan eksplanasi umum yang melatarbelakangi diadakannya penelitian terhadap Pelayanan Administrasi untuk proyek Bangunan Gedung Dalam Perspektif Pelayanan Publik yang Baik yang dituangkan ke dalam Bab I berisikan Pendahuluan yang di dalamnya akan diuraikan Latar Belakang Masalah dengan menelaah secara singkat alasanalasan yang memotivasi dilakukannya penelitian ini, dengan disertai, Perumusan Masalah, Tujuan Penelitian, Kegunaan Penelitian, Kerangka Pemikiran, Metode Penelitian serta Sistematika Penulisan.

Kemudian pada Bab II dengan pokok bahasan Tinjauan Pustaka dengan menyajikan tinjauan mengenai Konsep Negara Hukum, Konsep Negara Hukum Kesejahteraan, Konsep Negara Hukum Pancasila, Konsep Hukum Pelayanan Publik, Konsep Hukum Perizinan Untuk Proyek Bangunan Gedung.

Berikutnya dalam Bab III Hasil Penelitian dan Pembahasan meliputi Aspek Hukum Syarat Administrasi Untuk Proyek Bangunan Gedung Dalam Ketentuan Normatif Bangunan Gedung Yang Ada Sekarang, Penegakan Hukum Bangunan Gedung Melalui Implementasi Undang-Undang Nomor 28 Tahun 2002 Tentang Bangunan Gedung dan kendala- kendalanya , Analisa Hukum Terhadap Substansi Implementasi Ketentuan Normatif Tentang Bangunan Gedung , Aspek Hukum Syarat Administrasi Untuk Proyek Bangunan Gedung Dalam Perspektif Hukum Pelayanan Publik Yang Baik, dan Politik Hukum Pelayanan Syarat Administrasi Untuk Proyek Bangunan Gedung Di Masa Akan Datang

Dan terakhir dalam Bab IV ini akan di sajikan mengenai Penutup yang terdiri dari Kesimpulan dan Saran. Dan Pada Akhir Bab IV ini disertakan Daftar Pustaka.

\section{BAB II \\ TINJAUAN PUSTAKA}

\section{A. KONSEP NEGARA HUKUM}

Hukum adalah suatu tatanan perbuatan manusia, tatanan adalah suatu sistem aturan ${ }^{160}$ setiap peraturan hukum mewajibkan manusia untuk melakukan suatu perbuatan tertentu di bawah kondisi-kondisi tertentu. ${ }^{161}$

Ada tatanan hukum yang dari sudut pandang tertentu (dianggap.pen) tidak adil. Hukum dan keadilan adalah dua konsep yang berbeda. Hukum yang dibedakan dari keadilan adalah hukum positif $^{162}$

Jika hukum dan keadilan

\footnotetext{
${ }^{160}$ Hans Kelsen, 1971, General Theory of Law and State, Ne York :Russel and Russel dalam Terjemahan Raisul Muttaqien, 2010, Teori Umum Tetang Hukum dan Negara, Cet.V, hal. 3, Nusa Media, Bandung.

${ }_{161}^{162}$ Ibid., hal. 3

162 Ibid., hal.6
} 
disamakan, jika hanya tatanan yang adil saja yang disebut hukum maka tatanan sosial yang disebut hukum dalam waktu yang sama juga akan disebut adil, dan itu berarti bahwa tatanan sosial ini dibenarkan secara moral. Kecenderungan untuk menyamakan hukum dan keadilan merupakan kecenderungan untuk membenarkan tatanan sosial tertentu ${ }^{163}$

Jelaslah bahwa tidak mungkin ada tatanan hukum yang adil yakni tatanan yang memberikan kebahagiaan kepada setiap orang, bila kita mendifinisikan konsep kebahagiaan menurut pengertian aslinya yang sempit tentang kebahagiaan perseorangan, mengartikan kebahagiaan seseorang sebagai apa yang menurutnya memang demikian.

Tidak dipungkiri bahwa kebahagiaan seseorang pada suatu saat akan bertentangan secara langsung dengan kebahagiaan orang lain. Jadi, tidak mungkin pula adanya suatu tatanan yang adil meskipun atas dasar anggapan bahwa tatanan ini berusaha menciptakan bukan kebahagiaan sebesar-besarnya bagi seluruh masyarakat. ${ }^{164}$

Adapun kebahagiaan yang dapat di jamin oleh suatu tatanan sosial hanya bisa berupa kebahagian dalam arti kelompok, yakni terpenuhinya kebutuhankebutuhan tertentu, yang oleh penguasa mayarakat, yakni pembuat hukum, dianggap sebagai kebutuhan-kebutuhan yang patut dipenuhi, seperti kebutuhan

\footnotetext{
163 Ibid., hal.6

164 Ibid., hal. 7
}

pangan, sandang, dan papan. ${ }^{165}$

Hukum sebagai suatu sistem nilai positif bukanlah ciptaan dari orang perseorangan yang bersifat sembarangan, melainkan selalu merupakan hasil dari pengaruh timbal balik(konsensual.Pen) yang dilakukan antar individu di dalam suatu kelompok tertentu, baik itu keluarga, suku, kelas, kasta maupun kelompok profesi. ${ }^{166}$

Hubungan saling pengaruh mempengaruhi antara hukum dan lingkungan sosialnya atau dalam arti keberadaan hukum tidak luput dari keberadaan manusia yang terhimpun dalam suatu bahtera besar bernama negara, sehingga jika tidak ada manusia tidak ada negara dan hukum. ${ }^{167}$

\section{B. KONSEP NEGARA HUKUM KESEJAHTERAAN}

Konsep Negara kesejahteraan menjadi landasan kedudukan dan fungsi pemerintah (bestuursfunctie) dalam negara-negara modern. Negara kesejahteraan merupakan antithesis dari konsep Negara hukum formal klasik ${ }^{168}$ (rechtstaat dan the rule of law), yang dilandasi oleh keinginan penguasa (Negara atau raja) untuk melakukan pengawasan yang ketat dan bahkan cenderung ekstra ketat terhadap penyelenggaraan Negara, khususnya eksekutif, yang pada masa monarki absolute

\footnotetext{
165 Ibid., hal.7

${ }_{166}$ Ibid., hal. 9

167 Juniarso Ridwan dan Achmad SodikSudrajat, Ibid., hal. 46-47

${ }^{168}$ W. Riawan Tjandra, 2008,Ibid, hal.1
} 
Jurnal Law reform April 2010. Vol. 5. No.1

telah terbukti banyak melakukan penyalah gunaan kekuasaan.sehingga lebih dikenal dengan penjaga malam (nachtwakker) dan (nachtwakketstaat).

Meskipun sudah ada dua konsep negara hukum di atas, yaitu Rechtstaat (Eropa Kontinental) dan The Rule of Law (anglo Saxon) dimaksudkan untuk membentuk sistem pemerintahan yang didasari atas prinsip-prinsip keadilan dengan mengutamakan keseimbangan (Checks and balances) ${ }^{169}$, namun seiring perkembangan tingkat kompleksitas permasalahan yang mengakibatkan campur tangan Negara juga menjadi semakin luas dari mulai sejak manusia lahir sampai dengan manusia mati kesemuanya diatur oleh negara, berdasar latar belakang itulah maka terjadi perubahan paradigma baru yang apa bila dilihat perkembangannya dimulai dari konsep negara hukum (rechtstaat) di Kawasan Eropa continental yang dikembangkan oleh Immanuel Kant, Frederich Julius Stahl sebagaimana dikutip oleh Padmo Wahyono dan dikutip kembali oleh Muhammad Tahir Azhary mengemukakan

Negara hukum sebagai Nachtwaker staat atau Nachtwachterstaat (Negara jaga malam) yang tugasnya adalah menjamin ketertiban dan keamanan masyarakat. ${ }^{170}$

\footnotetext{
${ }_{170}^{169} \mathrm{lbid}$, hal.4

Padmo Wahyono, Konsep Yuridis Negara Hukum Indonesia", op.cit.hal.2. Sudargo Gautama, op.cit, hal.13., dalam Mohammad Tahir Azhary, Ibid., hal.89
}

Sedangkan di Kawasan Negaranegara Angelo Saxon konsep rule of law yang dikembangkan oleh A.V.Decey dengan cirinya yang menonjol yaitu ditegakkannya hukum yang adil dan tepat (just law) ${ }^{171}$, konsep negara tersebut seiring perkembangan zaman berubah menuju konsep negara kesejahteraan (welfarestaat) yang mengharapkan terciptanya keadilan bagi seluruh rakyatnya.

Hampir senada pendapat di atas Lunstedt seperti dikutip Achmad Ali mengemukakan bahwa

Law is simply the facts of social existence, all else is illusion. Law is essential if society is to endure its basis is, therefore, the very requirements of social welfare (Hukum sungguh-sungguh berwujud eksisitensi dari faktafakta sosial yang secara keseluruhan berbeda dari sekedar ilusi. Hukum sangat esensial jika masyarakatnya bertahan lama, inilah hal yang mendasar dari hukum. Maka sangat dibutuhkan kesejahteraan masyarakat). ${ }^{172}$ (garis bawah dari penulis)

Sementara itu, Padmo Wahyono seperti dikutip Muhammad Tahir Azhary mencatat bahwa

dalam perkembangannya pemerintahan yang berdasarkan undangundang dianggap "lamban" dan

\footnotetext{
${ }^{171}$ Padmo Wahyono, op.cit.hal.3 dalam Ibid., hal.91

${ }^{172}$ Curzon, L.B, 1979, Ibid., hal.27 dalam Achmad Ali, Ibid., hal.21
} 
karena itu diganti dengan pemerintahan yang berdasarkan hukum atau rechtmatige bestuur. Maka, Negara hukum yang formil menjadi Negara hukum yang materiil dengan ciri rechtmatige bestuur. Selan-jutnya lahirlah konsep-konsep yang merupakan variant dari rechtstaat itu antara lain welvarestaat dan verzorgingstaat sebagai Negara kemakmuran. ${ }^{173}$

Hal ini merupakan suatu condition sine qua non dalam hukum adalah keadilan. Mengenai masalah itu perlu diingat pandangan Gustav Radbruch seperti dikutip Piter Mahmud Marzuki yang secara tepat menyatakan bahwa cita hukum tidak lain dari pada keadilan. ${ }^{174}$ Selanjutnya Gustav Redbruch dikutip Peter Mahmud Marzuki mengemukakan bahwa

"Est autem jus a justitia, sicut a matre sua ergo prius fuit justitia quam jus" (akan tetapi hukum berasal dari keadilan seperti lahir dari kandungan ibunya, pendek kata adalah keadilan telah ada sebelum adanya hukum). ${ }^{175}$

Pada dasaranya persoalan keadilan ini bukan merupakan persoalan

\footnotetext{
173 Padmo Wahyono, op.cit.hal.2-3.tentang verzorgingstaat dapat dibaca dalam J.J.Vis,1978, Rechtstaat en verzorgingstaat., Kluwer,Deventer dalam Mohammad Tahir Azhary, Ibid., hal.90

174 Kurt Wilk, 1950, The Legal Philosophies of Lask, Redbruch, and Dabin, Havard University Press, Cambrige, Part. 73 dalam Peter Mahmud Marzuki, 2005, Penelitian Hukum, Ed. I. Cet. V, hal.23

${ }^{7}$ Ibid., hal. 23
}

matematis klasik, melainkan persoalan yang berkembang seiring dengan peradaban masyarakat dan intelektual manusia. $^{176}$

Dalam konsep negara kesejahteraan, campur tangan negara yang semakin luas untuk ikut terlibat mengatur setiap aspek kehidupan masyarakat pada setiap waktu dan pada segala sektor, seperti ekonomi, sosial, politik dan pertahanan dan keamanan negara. Singkatnya campur tangan negara adalah untuk membatasi hak-hak (hak objektif dan hak subjektif) setiap individu dalam masyarakat. Meskipun demikian, Hukum atau juga disebut hak objektif (Objectives recht atau droit objectif) dipandang sebagai peraturan,sedangkan hak subjektif didifinisikan sebagai kepentingan atau kehendak masing-masing individu yang terus berkembang sesuai zamannya. ${ }^{177}$

Sehubungan dengan adanya Objectives Recht atau droit objectif) dalam konsep negara hukum, menurut Philipus M.Hadjon dikutip W. Riawan Tjandra mengatakan bahwa

Dalam hukum administrasi asas legalitas dalam wujud wetmatigheid van bestuur sudah lama dirasakan sangat tidak memadai, meskipun disadari bahwa asas wetmatigheid menjamin pelaksanaan asas persamaan di hadapan hukum dan asas kepastian hukum.

Asas wetmatigheid berasal dari pe-

\footnotetext{
${ }^{176}$ Ibid, hal. 23

177 Hans Kelsen, Ibid., hal. 114
} 
Jurnal Law reform April 2010. Vol. 5. No.1

mikiran abad XIX yang dikuasai pemikiran negara undang-undang (wettenstaat). Sebaliknya, pemikiran negara hukum abad XX lebih mengedepankan doelstelling (penerapan tujuan), sedangkan wettenstaat mengedepankan normstelling (penerapan norma), lebih mengedepankan plan (rencana), dari pada voorschrif (instruksi), lebih mengedepankan beleid (kebijakan) dari pada uitvoering (pelaksanaan) atau topassing (penerapan). ${ }^{178}$

Sementara itu, menurut Kant dan Ficte sebagaimana dikatakan oleh Utrecht (1986:26) seperti dikutip W. Riawan Tjandra mengatakan bahwa

Tiap campur tangan negara dalam perekonomian dan segi-segi penghidupan sosial dilarang sekeraskerasnya, mereka mempertahankan suatu "staatsonthouding" sepenuhpenuhnya, yaitu suatu pemisahan antara negara dan masyarakat. Di suatu negara semacam itu pekerjaan pemerintah dengan sendirinya tidak luas. dan pemerintah negara semacam itu hanya bertugas membuat dan mempertahankan hukum, atau dengan kata lain hanya menjaga keamanan dengan arti penekanannya kepada pemaksaan sanksi saja. ${ }^{179}$

Lebih lanjut Utrecht dalam analisisnya yang dikutip W. Riawan Tjandra menyatakan bahwa

Suatu negara semacam itu, yang secara umum dikenal sebagai tipe Negara liberal, bertindak sebagai suatu penjaga malam (nacht waker), yang merupakan nacht wakerstaat.Ditinjau dari sudut politik, pada pokoknya tugas utama daripada nacht wakerstaat adalah menjamin dan melindungi kedudukan ekonomis dari mereka yang menguasai alat-alat pemerintahan (eksekutif, legeslatif dan yudikatif baik hubungan secara struktural dan substansinya.Pen)." nacht waker-staat" itu yaitu rulling class yang merupakan suatu golongan eksklusif.Nasib mereka yang rulling class tidak dihiraukan oleh alat-alat pemerintahan dalam suatu nacht wakerstaat. ${ }^{180}$

Seperti apa yang telah diungkapkan oleh Utrecht di atas, yaitu pemikiran yang dipengaruhi oleh ajaran Montesquieu, tersebut tidak dapat dipertahankan secara penuh, dinamika masyarakat inilah yang melatar belakangi diperlukannya penyesuaian terhadap paham Negara hukum formal, dan perubahan paradigma konsep Negara hukum (rechtstaat) menjadi konsep negara kesejahteraan (welfarestaat), di mana hukum masyarakat modern yang didasari oleh ajaran negara kesejahteraan (welfarestaat).

${ }^{180}$ Ibid, hal.4

${ }^{178}$ W. Riawan Tjandra, 2008, Ibid, hal. 4
179 lbid, hal.6 
C. KONSEP NEGARA HUKUM PANCASILA

Seperti telah di jelaskan dalam uraian sebelumnya yaitu mengenai Negara Indonesia adalah sebagai negara Hukum (rechtstaat),seperti disebutkan dalam penjelasan umum Undang-Undang Dasar 1945 mengenai Sistem Pemerintahan Negara Indonesia ialah berdasar atas hukum (rechtstaat), tidak berdasar atas kekuasaan belaka (Machtstaat) disini berarti bahwa negara Indonesia bukan merupakan negara hukum secara absolute yang menganut aliran Hobbesian, yang mana menurut Thomas Hobbes seperti dikutip Satjipto Rahardjo mengatakan bahwa

Untuk mendapatkan ketertiban di masyarakat semua orang harus tunduk pada negara, Masyarakat ditelan habis oleh negara itulah ongkosnya. ${ }^{181}$

Artinya mempercayakan (penciptaan) ketertiban masyarakat kepada hukum yang hanya bisa dikeluarkan oleh satu-satunya kekuasaan dan bila mana tanpa kekuasaan absolut yang menguasai seluruh masyarakat akan terjadi kekacauan dan pertentangan angotaanggota masyarakat, penganut Hobbesian untuk mendapatkan ketertiban di masyarakat sama sekali tidak ada ruang publik yang ada hanya ruang bagi negara sehingga segala urusan ketertiban masyarakat hanya bisa dilakukan lewat hukum (Negara, secara formil dan

$\overline{{ }^{181} \text { Satjipto Rahardjo, 2006, Ibid., hal.77-78 }}$
materiil.Pen), karena itu harus diserahkan kepada hukum sebagai satusatunya institusi yang mampu menuntaskan segalanya. ${ }^{182}$

Akan tetapi sebaliknya di Indonesia yang memberikan tempat bagi ruang publik atau peran serta masyarakat dalam mewujudkan ketertiban di dalam segala urusan atau sektor kehidupan, hal ini ditegasan oleh di dalam simposium di Universitas Indonesia tahun 1966 mengenai Indonesia Negara Hukum seperti dikutip Juniarso Ridwan dan Achmad Sodik Sudrajat yang dalam kesimpulannya dikemukakan

"Negara Indonesia adalah suatu Negara Hukum (rechtstaat) yang berdasarkan Pancasila....,", 183

Padmo Wahyono seperti tersebut dalam tulisan Muin Fahmal menelaah Negara hukum Pancasila dengan bertitik pangkal dari asas kekeluargaan yang tercantum dalam Undang-Undang Dasar 1945, hal ini tercermin di dalam Pasal 33 UUD 1945. ${ }^{184}$ Yang mana secara tegas menyatakan bahwa perekonomian disusun sebagai usaha bersama berdasar atas asas kekeluargaan, artinya bahwa yang penting adalah kemakmuran masyarakat dan bukan kemakmuran orang perseorangan. ${ }^{185}$

\footnotetext{
${ }_{183}^{182}$ Ibid., hal.77

183 Juniarso Ridwan dan Achmad Sodik Sudrajat, 2009, Hukum Administrasi Negara dan Kebijakan Pelayanan Publik, Cet.I, hal. 34, ${ }_{184}$ Penerbit NUANSA, Bandung.

${ }_{185}^{184}$ Muin Fahmal, op.cit. hal. 95

185 Ibid., hal.95
} 
Jurnal Law reform April 2010. Vol. 5. No.1

Masih terkait dengan negara hukum Pancasila Padmo Wahyono seperti ditulis Muin Fahmal, memahami bahwa hukum adalah suatu alat atau wahana untuk menyelenggarakan kehidupan negara atau ketertiban dan menyelenggarakan kesejahteraan sosial. Pengertian ini tercermin dari rumusan penjelasan Undang-Undang Dasar 1945 yang diantaranya berbunyi, “...UndangUndang Dasar hanya memuat aturanaturan pokok, hanya memuat garis-garis besar sebagai instruksi kepada Pemerintah Pusat dan lain-lain penyelenggaraan negara untuk menyelenggarakan kehidupan negara kesejahteraan sosial. ${ }^{186}$

\section{KONSEP HUKUM PELAYANAN PUBLIK}

Pelayanan Publik pada dasarnya merupakan titik singgung antara asasasas yang termaktub dan berlaku di dalam ranah Hukum Administrasi Negara, hal ini pernah dikemukakan oleh H.J. van Eikema Hommes seperti di sitir Soerjono Soekanto dan Sri Mamuji di dalam bukunya yang berjudul "Penelitian Hukum Normatif Suatu Tinjauan Singkat" yang menyebutkan bahwa : ${ }^{187}$

1. Asas tanggung jawab

\footnotetext{
186 Padmo Wahyono, 1983.,Indonesia Negara Berdasarkan Atas Hukum, hal.4 dan 27, Ghalia Indonesia, Jakarta dalam Muin Fahmal, 2006., lbid., hal.95.

${ }^{187}$ Soerjono Soekanto dan Sri Mamuji, Penelitian Hukum Normatif Suatu Tinjauan Singkat, Cet.II, hal. 74, Rajawali, Jakarta.
}

negara terhadap sikap tindak petugas negara atau pejabat negara

2. Asas bahwa perjanjian antara lembaga administrasi dengan pihak lain tidak boleh menghalangi penegakan aturan-aturan umum

3. Asas pemerintahan yang pantas (asas hukum regulatif khususnya adalah "salus publica seprema lex esto"

Gayut sambung dengan pendapat Soerjono Soekanto dan Srimamuji di atas, Hans Kelsen menambahkan bahwa Hukum yang muncul dalam bentuk undang-undang adalah hukum material (substantif) dan hukum formal (prosedural) ${ }^{188}$, hal ini sebagai ajudikasi, administrasi negara menunjukkan diri sebagai individualisasi dan konkretisasi undang-undang yaitu sebagai peraturan administrasi. Sebagian besar dari apa yang biasanya dikelompokkan sebagai administrasi negara memang tidak berbeda sama sekali, secara fungsional. ${ }^{189}$

Adapun tolok ukurnya adalah terletak pada substansi hukum dari aparat administrasi negara untuk mencapai tujuan negara, apa yang dinginkan masyarakat atau apa yang dianggap pembuat undang-undang sebagai keinginan masya-rakat diciptakan karena alat pemerintahan

\footnotetext{
${ }^{188}$ Hans Kelsen, Pengantar Teori Hukum, Ibid, hal.107

${ }^{189}$ Hans Kelsen, Pengantar Teori Hukum, Ibid, hal.111
} 
negara. ${ }^{190}$ Artinya terwujudnya kesejahteraan umum dalam konsep ini diukur dari wujud atau bentuk pelayanan publik yang diberikan oleh badan-badan penyelenggara administrasi negara kepada pengguna jasa pelayanan administrasi negara yang telah digariskan oleh ketentuan normatifnya yang ada sekarang ini.

\section{E. KONSEP HUKUM PERIZINAN UNTUK PROYEK BANGUNAN GEDUNG}

Dalam hukum Administrasi Negara, dikenal adanya lapangan hukum administrasi khusus yaitu peraturanperaturan hukum yang berhubungan dengan bidang tertentu dari kebijaksanaan penguasa seperti seperti halnya masalah hukum atas tata ruang dan hukum perizinan bangunan ${ }^{191}$ (hukum bangunan) yaitu meliputi status kepemilikan atau penguasaan hak atas tanah dan status kepemilikan bangunan gedung.

Menurut Hasnil Harun dalam Ensiklopedi Nasional Indonesia mengemukakan bahwa hukum bangunan gedung menyangkut ketentuan, peraturan, kebiasaan yang bertalian dengan berdirinya sebuah bangunan gedung untuk dimanfaatkan oleh manusia dan atau badan hukum, di mana

\footnotetext{
${ }^{190}$ Hans Kelsen, Pengantar Teori Hukum, Ibid, hal.111

Philipus M.Hadjon Cs, 2008, Pengantar Hukum Administrasi Indonesia (Introduction To The Indonesian Administrative Law), Cet.X, hal.32, Gajah Mada University Press, Yogyakarta.
}

hukum bangunan gedung dapat dikelompokkan menjadi dua yaitu: ${ }^{192}$

1. Yang menyangkut peraturan yang bertalian dengan prosedur (Administratif) sebelum bangunan gedung didirkan. Dalam arti ketentuan-ketentuan administratif (yang telah dipersyaratkan oleh peraturan perundang-undangan serta aturan pelaksanaannya tersebut) yang berlaku sebelum terjadinya kontrak pembuatan bangunan gedung (site acquisition,yaitu meliputi Status kepemilikan atau penguasaan hak atas tanah, status kepemilikan bangunan gedung dan Izin Mendirikan Bangunan.Pen),

2. Yang menyangkut peraturan yang bertalian dengan perjanjian serta pelaksanaan dan hal yang bersangkutan dengan bangunan gedung setelah didirikaan.

Lebih lanjut Hasnil Harun mengemukakan bahwa bagian hukum bangunan gedung ialah bagian tata hukum yang berkaitan dengan bangunan gedung atau tempat tinggal. Peraturan hukum bangunan gedung dapat meliputi masalah perizinan beserta persyaratanpersyaratan (dalam hal ini difokuskan pada persyaratan administratif) yang telah ditentukan oleh perundangundangan, ketentuan ini dapat berkembang sehingga meliputi persyaratan (teknis) yaitu meliputi

\footnotetext{
192 Hasnil Harun,2004, Ensiklopedi Nasional Indonesia, Cet.IV, Jilid.6, hal.487, PT. Delta Pamungkas, Jakarta.
} 
Jurnal Law reform April 2010. Vol.5. No.1

bahan-bahan bangunan, pembo-rongan bangunan gedung dan lain-lain. Pada jaman sekarang, hukum bangunan gedung berkaitan pula dengan hal ikhwal rumah susun baik dalam pemilikan maupun dalam penegelolaannya. ${ }^{193}$

\section{BAB III \\ HASIL PENELITIAN DAN PEMBAHASAN}

A. Aspek Hukum Syarat Administrasi Untuk Proyek Bangunan Gedung Dalam Ketentuan Normatif Bangunan Gedung Yang Ada Sekarang,

Dalam Bab III ini akan diawali dengan mendiskripsikan secara singkat satu persatu ketentuan persyaratan administrasi untuk proyek bangunan gedung dari perundang-undangan yang menjadi dasar hukum dalam penegakan hukum administrasi terhadap administrasi bangunan gedung, yaitu antara lain :

\section{A.1. Ketentuan Normatif Yang} Terkait Dengan Bagunan Gedung Saat Ini

\section{A.1.1. Undang-Undang Nomor 28} Tahun 2002 Tentang Bangunan Gedung

Rumusan difinisi bangunan gedung telah secara implisit ditemukan dalam Bab I tentang Ketentuan Umum, di mana

\footnotetext{
193 Hasnil Harun,2004, Ensiklopedi Nasional Indonesia, Cet.IV, Jilid.3, hal.137, PT. Delta Pamungkas, Jakarta.
}

pada Pasal 1 angka 1 dikatakan bahwa yang dimaksud dengan "Bangunan gedung adalah wujud fisik hasil pekerjaan konstruksi yang menyatu dengan tempat kedudukannya, sebagian atau seluruhnya berada di atas dan atau di dalam tanah dan atau air, yang berfungsi sebagai tempat manusia melakukan kegiatan baik untuk hunian atau tempat tinggal, kegiatan keagamaan, kegiatan usaha, kegiatan sosial, budaya, maupun kegiatan khusus." (garis bawah dari penulis).

Kemudian dari pada itu, menurut Undang-undang Nomor 28 Tahun 2002 tentang Bangunan Gedung dijelaskan bahwa setiap bangunan gedung memiliki fungsinya yang bereda-beda, mengenai hal ini dirumuskan dalam Bab III Pasal 5 yang mengidentifikasikan fungsi bangunan gedung.

Selanjutnya, Secara implisit Persyaratan administratif yang harus dipenuhi menurut Undang-Undang Nomor 28 Tahun 2002 tentang Bangunan Gedung adalah yang dirumuskan di dalam Pasal 8 ayat (1) huruf a, huruf b dan huruf $c$.

\section{A.1.2. Peraturan Pemerintah Nomor 36 tahun 2005 tentang Bangunan Gedung.}

Mengingat pentingnya persyaratan administratif bangunan gedung sebagai wujud tertib dan kepastian hukum, maka pengaturan tentang persyaratan administratif ini di atur lebih lanjut di 
dalam Peraturan Pemerintah Nomor 36 tahun 2005 tentang Bangunan Gedung.

Dari uraian Penjelasan umum Peraturan Pemerintah tersebut di atas, untuk selanjutnya dapat di ketahui bahwa pada hakekatnya dalam Implementasinya pengaturan bangunan gedung di Indonesia secara umum terbagi menjadi tiga bagian yaitu meliputi ketentuan mengenai hal-hal sebagai berikut :

\section{A.1.2.1. Fungsi Bangunan Gedung}

Penjabaran pengaturan fungsi bangunan gedung sebagai ketetapan pemenuhan persyaratan teknis yang termuat di dalam Bab ketiga Pasal 5 Joncto Pasal 7 ayat (1) Joncto Pasal 7 ayat (3) Undang-Undang Nomor 28 Tahun 2002 tentang Bangunan Gedung, untuk selanjutnya diuraikan secara detail dalam rumusan Pasal 3 dan Pasal 4 Peraturan Pemerintah tentang Bangunan Gedung.

\section{A.1.2.2. Persyaratan Administratif Ba- ngunan Gedung}

Seperti telah diuraikan di muka, bahwa pada prinsipnya agar setiap bangunan gedung yang berdiri di Negara Republik Indonesia ini memiliki jaminan kepastian dan tertib hukum sudah seharusnya memenuhi dua unsur kesempurnaan suatu bangunan gedung yaitu terpenuhinya persyaratan administratif meliputi Persyaratan status hak atas tanah, persyaratan status kepemilikan bangunan gedung dan Izin mendirikan bangunan. Dan persyaratan teknis meliputi persyaratan tata bangunan dan keandalan bangunan sesuai peraturan perundang-undangan yang berlaku.

\section{A.1.2.3. Persyaratan Teknis Bangunan Gedung}

Seperti telah di uraikan di muka, bahwa setiap bangunan gedung yang akan dan atau sudah berdiri selain harus memenuhi persyaratan admnistrasi, juga harus memenuhi persyaratan teknis yang meliputi persyaratan tata bangunan dan persyaratan keandalan bangunan gedung.

Mengenai pengaturan persyaratan teknis ini telah dirumuskan di dalam Pasal 9 samapai dengan Pasal 9 sampai dengan Pasal 32 Undang-undang Nomor 28 tahun 2002. Yang mana selanjutnya dari pasal-pasal tersebut diuraikan lebih lanjut di dalam Peraturan Pemerintah Tentang Bangunan Gedung ini, yang terbagi dalam dua bagian yaitu Pasal 16 sampai dengan Pasal 95 mengatur tentang persyaratan teknis bangunan gedung tentang tata bangunan meliputi per-syaratan peruntukan dan intensitas, per-syaratan arsitektur, persyaratan pengen-dalian dampak lingkungan, rencana tata bangunan dan lingkungan (RTBL) serta pembangunan bangunan gedung di atas dan atau di bawah tanah, air dan atau prasarana atau sarana umum. Sedangkan Pasal 31 sampai dengan Pasal 61 mengatur tentang persyaratan keandalan bangunan gedung meliputi persyaratan keselamatan, persyaratan 
Jurnal Law reform April 2010. Vol.5. No.1

kesehatan, persyaratan kenyamanan, dan persyaratan kemudahan.

\section{A.1.3. Peraturan Menteri Pekerjan} Umum Nomor 24 Tahun 2006 Tentang Pedoman Teknis Izin Mendirikan Bangunan Gedung Pegaturan lebih lanjut dari persyaratan adminitratif bangunan gedung seperti dirumuskan di dalam Pasal 8 ayat (1) huruf c UU No. 28 tahun 2002 dan Pasal 8 ayat (2) huruf c serta Pasal 14 dan Pasal 15 PP No. 36 tahun 2005 di uraiakan di dalam Peraturan Menteri Pekerjaan Umum No. 24 tahun 2006 ini.

Selanjutnya secara garis besar Pedoman teknis dari Peraturan Menteri ini memuat tentang difinisi izin mendirikan Bangunan Gedung dan terdiri dari lima bab dan 12 (dua belas) pasal. Dari pasal yang terpenting yang menjadi arahan atau acuan bagi pemerintah daerah adalah Bagian I Pasal 3 dan Pasal 4.

\section{A.2. Ketentuan Normatif Administrasi} Untuk Proyek Bangunan Gedung Di Luar Ketentuan Normatif Yang Ada Sekarang Ini.

\section{A.2.1. Undang-Undang Nomor 4} Tahun 1992 Tentang Perumahan dan Permukiman.

Undang-undang Nomor 4 Tahun 1992 ini mengatur memiliki keterkaitan erat dengan Pasal 1 angka 1 Undangundang Nomor 28 tahun 2002 yaitu mengenai difinisi bangunan gedung. Di mana di dalam Undang-undang Perumahan dan Permukiman ini mengatur secara parsial mengenai bangunan gedung yang memiliki fungsi sebagai hunian atau tempat tinggal atau di dalam hal ini disebut dengan perumahan dan permukiman.

\section{A.2.2. Undang-Undang Nomor 26 Tahun 2007 Tentang Penataan Ruang}

Mengingat kembali sejenak mengenai difinisi pasal 1 ayat 1 dan penjelasan umum alenia ketiga Undangundang Nomor 28 tahun 2002 tentang Bangunan Gedung, yang bunyinya antara lain bahwa bangunan gedung adalah wujud fisik hasil pekerjaan konstruksi yang menyatu dengan tempat kedudukannya, sebagian atau seluruhnya berada di atas tanah dan atau air .......dan seterusnya. Selanjutnya bunyi penjelasan umum alenia ketiga UU Bangunan Gedung selengkapnya yaitu "Bangunan gedung merupakan salah satu wujud fisik pemanfaatan ruang.

\section{A.2.3. Undang-undang 32 Tahun 2009 Tentang Perlindungan Dan Pengelolaan Lingkungan Hidup}

Seperti telah dikemukakan di atas bahwa bangunan gedung sebagai wujud fisik hasil pekerjaan kostruksi yang menyatu dengan tempat kedudukannya, sebagian atau seluruhnya berada di atas dan atau di dalam tanah dan atau air....dst, selain itu juga berdirinya suatu 
bangunan gedung juga memiliki dampak terhadap lingkungan sekitarnya seperti dirumuskan di dalam Pasal 14 ayat (5) dan Pasal 15 ayat (1) yang di antaranya menyebutkan bahwa Penerapan persyaratan pengendalian dampak lingkungan hanya berlaku bagi bangunan gedung yang dapat menimbulkan dampak penting terhadap lingkungan.

\section{B. Penegakan Hukum Bangunan Gedung Melalui Implementasi Undang-Undang Nomor 28 Tahun 2002 Tentang Bangunan Gedung dan kendala-kendalanya}

Seperti telah dijelaskan dari uraian di atas dapat ditelaah bahwa penjabaran rumusan dari pasal 8 ayat (1) UU Nomor 28 tahun 2002 dan Pasal 8 ayat (2) Peraturan Pemerintah Nomor 36 tahun 2005 tentang Bangunan Gedung tidak hanya berhenti pada Pasal 12 sampai dengan Pasal 15 Peraturan tersebut, melainkan dalam rangka penegakan hukumnya. Penjabaran Pasal-pasal dimaksud di telaah sampai dengan aturan peralihannya.

Penegakan hukum di bidang bangunan gedung akan dapat diukur secara konkrit dari setiap norma-norma serta kaidah-kaidah di dalam ketentuan normatifnya yang menjadi obyek kognisi hukum normatif, namun norma diterapkan hanya sebagai sebuah kerangka yang memberikan berbagai kemungkinan aplikasi atau implementasi dari setiap tindakan administrasi negara yang ada di dalam kerangka ini. ${ }^{194}$

Jadi di dalam Implementasi pelayanan administrasi untuk proyek bangunan gedung sebagai cerminan sebuah sistem hukum dari koersif negara yang berupa ketentuan normatif atau undang-undang bangunan gedung yang ada saat ini yaitu Undang-Undang Nomor 28 Tahun 2002 tentang Bangunan Gedung, tidak harus menghasilkan sebuah keputusan tunggal sebagai satusatunya keputusan yang tepat, tetapi mungkin menghasilkan sejumlah keputusan yang dari semua keputusan tersebut berkedudukan sama. Hal ini hanya diukur terhadap norma atau perundang-undangan yang diterapkan, meskipun hanya salah satu dari keputusan-keputusan tersebut yang dalam tindakan keputusan hakim menjadi hukum positif. ${ }^{195}$

Menurut Penulis Banyak faktor yang mempengaruhi timbulnya sengketa administrasi IMB ini, dari hasil telaah berbagai putusan hakim dan kepustakaan dapat ditemukan akar permasalahannya di antaranya adalah :

1. Batalnya penerbitan IMB akibat tanah masih sengketa atau status tanah tidak jelas.

2. Tidak adanya kejelasan kepemilikan bangunan gedung.

\footnotetext{
${ }^{194}$ Hans Kelsen, 2009, Pengantar Teori

hukum...lbid, hal.125

195 Hans Kelsen, 2009, Pengantar Teori Hukum, Ibid, hal.126
} 
Jurnal Law reform April 2010. Vol. 5. No.1

3. Batalnya penerbitan IMB akibat proyek tidak sesuai Rencana Tata Ruang dan Wilayah Daerah

4. Batalnya penerbitan IMB akibat tidak ada ijin prinsip dari Kepala Daerah

5. Batalnya penerbitan IMB akibat dari tidak adanya izin lokasi, izin lingkungan dan atau amdal.

\section{Analisa Hukum Terhadap Substansi Implementasi Ketentuan Normatif Tentang Bangunan Gedung}

Dari hasil pengkajian dan telaah terhadap baberapa kasus yang timbul akibat persyaratan administrasi untuk proyek bangunan gedung di antaranya di Ujung Pandang, Jakarta Selatan dan Jakarta Timur di bawah berikut ini dapat diketahui bahwa pada tahap implementasi Undang-undang Nomor 28 tahun 2002 tentang Bangunan Gedung ditemukan beberapa putusan pengadilan yang rumusannya mengacu atau merujuk pada rumusan Pasal 8 ayat (1) Undangundang tersebut serta rumusan Pasal 8 ayat (2), Pasal 11, Pasal 12, Pasal 13, Pasal 14 dan Pasal 15 PP No.36 Tahun 2005

1) Putusan Mahkamag Agung RI No. 484 K/TUN/2007 Tanggal 05 Maret 2008Tentang Penolakan Izin Mendirikan Bangunan

Jadi, tindakan Penolakan permohonan izin mendirikan bangunan tersebut menurut S.F. Marbun yang ditulis kembali oleh Adrian Sutedi dalam buku "Hukum Perizinan Dalam Sektor Pelayanan Publik" termasuk dalam kategori Vrij Bestuur atau discriotiner. ${ }^{196}$

\section{2) Putusan Mahkamah Agung RI} Nomor : 144 K/TUN/1998 tanggal 29 September 1999 Sengketa Surat Perintah Pembongkaran Kios

Pertimbangan Majelis kasasi tersebut bila di cermati secara keperdataan memang sudah tepat yaitu bahwa onrechtmatige overheidsdaad adalah kompetensi Peradilan Umum sesuai Pasal 2 huruf b UU No. 9 tahun 2004. Akan tetapi, bila dikaitkan dengan dampak implikasi dari Surat Perintah Pembongkaran tersebut menimbulkan akibat hukum yang merugikan masyarakat.

Maka berdasarkan hal tersebut, sudah selayaknya surat perintah pembongkaran yang diikuti tindakan pembongkaran oleh tim yustisi merupakan tindakan bestuurdwang dari pejabat administrasi Negara yang menyimpang dari peraturan dasarnya (Detournement de Pouvoir). Buktinya tindakan Tim Yustisi melakukan

\footnotetext{
${ }^{196}$ S.F. Marbun, 2003, Peradilan Tata Usaha Negara,Cet. II, hal. 124 Liberty, Yogyakarta. Dalam Adrian Sutedi, 2010, Ibid, hal.453. memberikan contoh lain dalam vrij Bestuur, misalnya mengabulkan atau menolak suatu permohonan Izin Mendirikan Bangunan, Izin UU gangguan.
} 
pembongkaran kios tersebut sudah tepat karena berdasarkan hukum yaitu surat perintah Pembongkaran dari Wali Kota Madya Ujung Pandang yang menurut penulis dapat dinggap sebagai produk hukum pemerintah daerah (eksekutif) yang bersifat memaksa atau bestuurdwang berarti menurut Spelt dan Ten Berge dalam buku Adrian Sutedi berjudul "Hukum Perizinan Dalam Sektor Pelayanan Publik" adalah wewenang organ pemerintah untuk menyesuaikan suatu situasi tidak sah, yang terjadi karena suatu kewajiban yang timbul dari norma hukum administrasi tidak ditunaikan dengan nyata pada norma ini. ${ }^{197}$ wewenang yang bersifat bebas semacam ini sebagai implementasi asas vrij bestuur atau descriotiner yaitu suatu wewenang di mana peraturan dasarnya memberikan ruang lingkup yang longgar atau bebas kepada badan atau pejabat TUN untuk menggunakan wewenang yang dimilikinya. ${ }^{198}$

3) Keputusan Mahkamah Agung Nomor 14 K/TUN/1992 Tanggal 10 Desember 1992 Perkara Pembatalan Hak Guna Bangun Yang Berdampak Pecabutan Izin Mendirikan Bangunan. ${ }^{199}$

\footnotetext{
197 Pilipus M. Hadjon, 1993, Pengantar Hukum Perizinan,...lbid, hal. 75 dalam dalam Adrian Sutedi, 2010, Hukum Perizinan Dalam Sektor Pelayanan Publik, Ed.I,Cet.I hal.453, Sinar Grafika, Jakarta

S.F. Marbun, 2003, Ibid, hal. 124 dalam Adrian Sutedi, 2010, Ibid, hal.453.

199 Adrian Sutedi, 2010, Hukum Perizinan Dalam Sektor Pelayanan Publik"., Ibid, hal.370-375
}

Dalam Perkara ini penulis hanya membatasi dasar pertimbangan Majelis hakim mulai dari Pengadilan Tingkat Pertama, Tingkat banding dan Kasasi yang terkait dengan Implementasi Pasal 8 ayat (1) huruf a, huruf b dan huruf $c$ yang mengatur tentang Persyaratan Adminitratif Bangunan Gedung meliputi : persyaratan administratif berupa kejelasan status Kepemilikan hak atas tanah dan atau Ijin pemanfaatan tanah, Persyaratan administratif berupa kejelasan status kepemilikan bangunan gedung dan Izin Mendirikan Bangunan.

\section{Aspek Hukum Syarat Administrasi Untuk Proyek Bangunan Gedung Dalam Perspektif Hukum Pela- yanan Publik Yang Baik \\ Ada beberapa faktor yang sangat} berpengaruh terhadap implementasi ketentuan persyaratan administratif bangunan gedung yang meliputi persyaratan kejelasan status hak atas tanah dan atau pemanfaatan tanah, kejelasan status kepemilikan bangunan gedung dan Izin Mendirikan Bangunan, di antaranya adalah faktor pelayanan administrasi untuk proyek bangunan gedung belum mencerminkan pelayanan publik yang baik. ${ }^{200}$ dan akibatnya muncullah berbagi

\footnotetext{
${ }^{200}$ www. Bataviase.co.id, Koran Tempo Nasional, 09 Jan 2010, Sanksi Kasus Tanah Abang Segera Diputuskan., Sebagai contoh adanya keengganan masyarakat memenuhi syarat Administratif tersebut, yaitu kasus robohnya bangunan Pasar Metro Tanah Abang yang runtuh pada 23 Desember 2009 lalu. Musibah itu menewaskan empat orang dan melukai 13 orang lainnya, menurut Kepala Dinas Penataan
} 
macam sengketa dibidang administrasi ${ }^{201}$ yang berkaitan dengan persyaratan administratif bangunan gedung. ${ }^{202}$

Pada dasarnya Penyelenggaraan Pelayanan Administrasi untuk proyek bangunan gedung adalah merupakan salah satu bagian amanat Pasal 28f Undang-Undang Dasar 1945 dan Undang-Undang Nomor 39 tahun 1999

dan Pengawasan Bangunan (P2B) DKI Jakarta Hari Sasongko menjelaskan, putusan sanksi itu akan diberikan jika didukung alat bukti yang kuat, meskipun secara nyata, bangunan induk gedung Metro Tanah Abang sebenamya telah mengantongi izin sejak 2005. "Namun ada bagian tambahan yang tidak disampaikan dalam laporan, yakni perluasan toilet. Itu yang menjadi masalah," dari kasus itu terindikasi sejumlah pelanggaran atas aturan seperti tercantum dalam Undang-Undang Nomor 28 Tahun 2002 tentang Bangunan Gedung aturan pelaksanaannya yaitu Peraturan Pemerintah Nomor 36 Tahun 2005,. "Dugaan kesalahannya beragam, mulai masalah administrasi, perencanaan, hingga masalah konstruksi

${ }^{201}$ Soetomo, tth, Hitamnya Peradilan, Ruwetnya Mencari Keadilan Hukum Di Indonesia, Cet.I, hal.125-126, PT. Nice World, Jakarta, Dan sebaliknya,ada hal menarik untuk dicermati dari contoh kasus Sengketa Tanah Tower V Taman Rasuna Said Jakarta Selatan antara Dr. Soetomo dengan PT. Catur/Bakrie Swasakti Utama Milik Bakrie Group di Pengadilan Negeri Jakarta Selatan Nomor 402/Pdt.G/2004/PN.Jak.Sel tanggal 18 Januari 2005 yang dikuatkan dengan Putusan Pengadilan Tinggi DKI Jakarta Nomor 344/Pdt/2006/PT.DKI tanggal 31 Januari 2007, yang mana PT. CSU/BSU tersebut dengan mudah mendapatkan IMB Nomor 04724/IMB/97 tertanggal 25 Juni 1997, namun realitanya walau pun sudah mendapatkan IMB tersebut tetapi tidak ada tanahnya.

202 RRI Pro3 FM, www.RRI Pro3.com, $12 \mathrm{Mei}$ 2010, Begitu juga dengan kasus sengketa lahan yang terjadi beberapa waktu lalu yang muncul sebagai dampak keputusan Gubernur DKI No.132 Tahun 2009 tanggal 9 September 2009 mengenai Penertiban Bangunan di atas tanah milik Pelindo Koja Jakarta Utara, mengakibatkan bentrok antara Satpol PP dengan Masyarakat Koja yang memakan korban tewas. tentang Hak Asasi Manusia, yang mana di dalamnya tersirat bahwa setiap warga Negara berhak untuk memperoleh pelayanan yang diberikan oleh pemerintah.

Sehubungan sejak disahkannya Undang-Undang Nomor 25 tahun 2009 tentang Pelayanan Publik tanggal 18 Juli 2009 silam, diharapkan pelayanan administrasi untuk proyek bangunan gedung akan semakin efektif, efisien dan optimal, dengan mengacu pada Pasal 21 undang-undang Pelayanan Publik tersebut yang menentukan Komponen standar pelayanan atau tolok ukur pelayanan sekurang-kurangnya meliputi :

1. Dasar hukum

2. Persyaratan

3. Sistem, mekanisme dan prosedur

4. Jangka waktu penyelesaian

5. Biaya/tarif

6. Sarana, prasarana dan atau fasilitas

7. Komponen pelaksana

8. Pengawasan internal

9. Penananganan pengaduan, saran dan masukan

10. Jumlah pelaksana

11. Jaminan pelayanan yang memberikan kepastian pelayanan dilaksanakan sesuai dengan standar pelayanan

12. Jaminan keamanan dan keselamatan pelayanan dalam bentuk komitmen untuk memberikan rasa aman, bebas dari bahaya dan resilo keraguraguan; dan

13. Evaluasi kinerja pelaksana. 
Sehingga dengan adanya komponen standar pelayanan tersebut, maka setiap pelayanan persyaratan administratif bangunan gedung dapat diukur seberapa baik pelayanan administrasi tersebut diselenggarakan oleh pemerintah (bestuur) dalam menjalankan kewenangannya secara bebas sesuai asas Freies Ermessen.

\section{E. Politik Hukum Pelayanan Ad- ministrasi Untuk Proyek Bangu- nan Gedung Di Masa Akan Datang}

Seperti telah dikemukakan di atas bahwa pada prinsipnya secara umum tolok ukur pelayanan administrasi untuk proyek bangunan gedung telah digariskan di dalam Pasal 21 UndangUndang Nomor 25 Tahun 2009 yang diundangkan pada tanggal 18 Juli 2009 lalu. Selanjutnya tersangkut ketentuan persyaratan administratif bangunan gedung yang telah ditentukan di dalam rumusan Pasal 7 ayat (2) dan Pasal 8 ayat (1) Undang-Undang Nomor 28 tahun 2002 tersebut di atas, dapat diketahui bahwa Komponen standar pelayanan administrasi untuk proyek bangunan gedung masih perlu dilakukan pengkajian secara komprehensif menyeluruh baik dalam tataran Implementasi dan atau pun dalam tataran praksis.

Hal ini pernah disinggung oleh Bagir Manan yang mengemukakan ketaatan dan kepatuhan pejabat tata usaha Negara (administarasi Negara) bukan saja penting berdasarkan prinsip "negara berdasarkan atas hukum" (de rechtsstaat) tetapi merupakan salah satu tiang utama "good governance" yang menjadi buah bibir sekarang ini. ${ }^{203}$

\section{BAB IV \\ PENUTUP}

\section{A. KESIMPULAN}

Berdasarkan rangkaian uraian dari bab-bab di muka yang secara garis besar memfokoskan terhadap persoalan mengenai Pelayanan Administrasi Untuk Proyek Bangunan Gedung Dalam Perspektif Pelayanan Publik Yang Baik, maka dapat ditarik benang merah kesimpulan sebagai berikut :

1. Dalam rangka menjamin kepastian dan ketertiban hukum penyelenggaraan bangunan gedung, maka setiap bangunan gedung harus memenuhi persyaratan administratif yang meliputi kejelasan status hak atas tanah, kejelasan status kepemilikan bangunan gedung dan Izin Mendirikan bangunan, yang secara normatif telah dirumuskan di dalam ketentuan fundamentalnya yaitu Undang-undang Nomor 28 tahun 2002 tentang Bangunan Gedung, Peraturan Pemerintah Nomor 36 Tahun 2005 Tentang Bangunan Gedung dan PERMEN PU Nomor 24 Tahun 2006 Tentang Pedoman Teknis Izin Mendirikan Bangunan.

\footnotetext{
203 Bagir Manan, 2005, Kumpulan Naskah Pidato...., Op.Cit., hal. 60
} 
Jurnal Law reform April 2010. Vol. 5. No.1

2. secara substansial pada tataran nilai implementasinya masih relatif banyak kendala-kendala dalam pelayanan administrasi untuk proyek bangunan gedung sejarang ini, yang tentu sangat menghambat terwujudnya penegakan hukum (law enforcement) bangunan gedung (das sein). Adapun kendala-kendala tersebut dapat dikelompokkan dalam tiga bagian yaitu:

Pertama, pada syarat Pelayanan administrasi terkait kejelasan status hak atas tanah kendala yang dihadapi antara lain (1) belum adanya integrasi substansi hukum dari ketentuan Normatif tentang bangunan gedung yang ada saat ini dengan ketentuan normatif tentang tertib administrasi pertanahan mengakibatkan lambatnya dan mahalnya pelayanan adminitrasi ini. (2) masih adanya kerancuan pengaturan nilai fundamental terhadap kompetensi institusi penyelenggara pelayanan administrasi tersebut berakibat tidak jelasnya sinkronisasi hubungan kedah menegenai persyaratan administrasi untuk proyek bangunan dengan perundang-undangan terkait, terbukti pada Penjelasan Undang-Undang Nomor 22 tagun 1999 yang menerangkan bahwa pada dasarnya kewenangan administrasi tentang status tanah semestinya adalah letak kompetensinya berada pada Pemerintah daerah dan bukan lagi sebagai kompetesi BPN atau kepala Kantor pertanahan. (3) dalam implementasinya dengan adanya dua persyaratan administrasi berupa sertifikat hak atas tanah dan sertifikat kepemilikan bangunan gedung yang berdiri sendiri-sendiri dan dengan kewenangan pengurusannya terpisah dan berbeda, menimbulkan kendalakendala yang signifikan. Hal ini terlihat adanya gejala-gejala pelanggaran ketentuan normatif tersebut di dalam Penyelenggaraan Proyek bangunan gedung, baik ditinjau dari segi substansi hukumnya maupun segi kultur hukumnya.

Kedua, Tolok ukur untuk dapat mengidentifikasikan kendala tersebut sangat jelas ditemukan adanya pengaturan normatif yang menentukan kewenangan institusi sebagai bagian dari substansi hukum yang ada saat ini, yaitu untuk persyaratan administrasi status hak atas tanah penerbitan sertifikat hak atas tanah menjadi kewenangan Badan Pertanahan Nasional (BPN/ Kantor Pertanahan Kabupaten atau Kota Madya), pada tertib administrasi pertanahan ini masih ada kendala berupa biaya percepatan sertifikat hak atas tanah sehingga biaya makin mahal dan tidak menentu dan sedangkan pengaturan penerbitan persyaratan administrasi kepemilikan atas bangunan gedung yang seharusnya diatur dengan 
Peraturan Presiden (lihat Pasal 12 ayat 4 PP No.36 tahun 2003) namun sampai sekarang Perpres tersebut tidak ada dan Pemberian Izin Mendirikan Bangunan menjadi kewenangan Pemerintah daerah dan atau pun Pemerintah Pusat.

Ketiga, pada ketentuan administrasi Izin Mendirikan Bangunan pengaturannya antara daerah yang satu dan daerah lainnya masih berbeda-beda dan tidak terintegrasi.

secara garis besar dari hasil analisa substansi ketentuan normatif tentang Bangunan Gedung ditemukan kendala penegakan hukum bagunan gedung yang dipengaruhi aspek-aspek hukum berupa Status kepemilikan tidak jelas dan atau tanah masih sengketa, Proyek bangunan gedung tidak sesuai Rencana Tata Ruang dan Wilayah Daerah, Proyek bangunan gedung tidak memiliki ijin prinsip dari Kepala Daerah, Proyek bangunan gedung tidak adanya izin lokasi dan amdal.

3. Keberhasilan Penegakan Hukum bangunan gedung sudah semestinya didukung oleh substansi sistem hukum yaitu alat pemerintahan resmi negara atau penyelenggara pelayanan administrasi Persyaratan administrasi untuk proyek bangunan gedung secara profesional yang transparan, adil, tertib hukum, partisipatif, tanggap,akuntabilitas, efisien dan efektif, serta profesional, merupakan wujud sistem hukum koersif pelayanan prima yang secara normatif seharusnya diberikan oleh pemerintah daerah dan Badan Pertanahan Nasional.

Dengan merujuk atau mengacu kepada Pasal 21 UndangUndang Nomor 25 tahun 2009 tentang Pelayanan Publik yang telah menentukan Komponen standar pelayanan atau tolok ukur pelayanan

politik hukum bangunan gedung yang meliputi law reform dan law development secara berkesinambunagan (sustanable) pembangunan sistem hukum dalam rangka menyelesaikan persoalan hukum administrasi bangunan gedung yaitu dengan mengintegrasikan seluruh sistem hukum bangunan gedung yang telah ada dengan sistem hukum pelayanan publik meliputi struktur hukumnya atau aturannya, substansi hukumnya (pejabat-pejabat administrasinya atau institusinya) dan masyarakatnya.sebagai wujud pemerintahan yang baik dan bersih yang di agungagungkan dan diharapkan oleh seluruh masyarakat Indonesia. Yaitu pemerintahan yang menjalankan tugas negaranya berdasarkan asas Freies Ermennsen yang melekat pada setiap pejabat-pejabat administrasi negara, namun dengan tetap pada bingkai sistem hukum yang ada atau sesuai ramburambu dan asas-asas hukum yang berkarakter responsif dan bersifat aspiratif dan proporsional serta 
Jurnal Law reform April 2010. Vol. 5. No.1

mempertimbangkan karakteristik lokal Detournement de Pouvoir ketika dan dinamika masyarakatnya di era menjalankan fungsi administrasi negara. global agar tidak di anggap sewenangwenang atau dikenal dengan asas 